\title{
Geochemical constraints on volatile sources and subsurface conditions at Mount Martin, Mount Mageik, and Trident Volcanoes, Katmai Volcanic Cluster, Alaska
}

T. Lopez ${ }^{\text {a,* }}$, F. Tassi ${ }^{\text {b,c }}$, A. Aiuppa ${ }^{\text {d,e }}$, B. Galle ${ }^{\text {f }}$, A.L. Rizzo ${ }^{\text {e }}$, J. Fiebig ${ }^{g}$, F. Capecchiacci ${ }^{\text {b,c }}$, G. Giudice ${ }^{\text {, }}$ S. Caliro ${ }^{\text {h }}$, G. Tamburello ${ }^{\text {i }}$

a University of Alaska Fairbanks, Geophysical Institute/Alaska Volcano Observatory, 903 Koyukuk Drive, Fairbanks, AK 99775, USA

b Dipartimento di Scienze della Terra, Università degli Studi di Firenze, Via La Pira 4, Florence 50121, Italy

c Consiglio Nazionale delle Ricerche - Istituto di Geoscienze e Georisorse, Via La Pira 4, Florence 50121, Italy

' DiSTeM, Università di Palermo, Via Archirafi 36, Palermo 90123, Italy

e Istituto Nazionale di Geofisica e Vulcanologia, Sezione di Palermo, Via Ugo La Malfa 153, 90146 Palermo, Italy

${ }^{\mathrm{f}}$ Chalmers University of Technology, Horsalsvagen 11, SE-412 96 Gothenburg, Sweden

${ }^{\mathrm{g}}$ Institute of Geosciences, Goethe University, 60438 Frankfurt, Germany

h Istituto Nazionale di Geofisica e Vulcanologia, Sezione di Napoli Osservatorio Vesuviano, Via Diocleziano, 32-80124 Napoli, Italy

i Istituto Nazionale di Geofisica e Vulcanologia, Sezione di Bologna, Via Donato Creti 12, Bologna 40128, Italy

\section{A R T I C L E I N F O}

\section{Article history:}

Received 15 April 2017

Received in revised form 6 August 2017

Accepted 7 September 2017

Available online 9 September 2017

\begin{abstract}
A B S T R A C T
We use the chemical and isotopic composition of volcanic gases and steam condensate, in situ measurements of plume composition and remote measurements of $\mathrm{SO}_{2}$ flux to constrain volatile sources and characterize subvolcanic conditions at three persistently degassing and seismically active volcanoes within the Katmai Volcanic Cluster (KVC), Alaska: Mount Martin, Mount Mageik and Trident. In situ plume measurements of gas composition were collected at all three volcanoes using MultiGAS instruments to calculate gas ratios (e.g. $\mathrm{CO}_{2} / \mathrm{H}_{2} \mathrm{~S}, \mathrm{SO}_{2}$ / $\mathrm{H}_{2} \mathrm{~S}$ and $\mathrm{H}_{2} \mathrm{O} / \mathrm{H}_{2} \mathrm{~S}$ ), and remote measurements of $\mathrm{SO}_{2}$ column density were collected from Mount Martin and Mount Mageik by ultraviolet spectrometer systems to calculate $\mathrm{SO}_{2}$ fluxes. Fumaroles were directly sampled for chemical and isotopic composition from Mount Mageik and Trident. Mid Ocean Ridge Basalt (MORB)-like ${ }^{3} \mathrm{He} /{ }^{4} \mathrm{He}$ ratios $\left(\sim 7.2-7.6 \mathrm{R}_{\mathrm{C}} / \mathrm{R}_{\mathrm{A}}\right)$ within Mount Mageik and Trident's fumarole emissions and a moderate $\mathrm{SO}_{2}$ flux ( $75 \mathrm{t} / \mathrm{d})$ from Mount Martin, combined with gas compositions dominated by $\mathrm{H}_{2} \mathrm{O}, \mathrm{CO}_{2}$ and $\mathrm{H}_{2} \mathrm{~S}$ from all three volcanoes, indicate magma degassing and active hydrothermal systems in the subsurface of these volcanoes. Mount Martin's gas emissions have the lowest $\mathrm{CO}_{2} / \mathrm{H}_{2} \mathrm{~S}$ ratio $(\sim 2-4)$ and highest $\mathrm{SO}_{2}$ flux compared to the other KVC volcanoes, indicative of shallow magma degassing. Geothermometry techniques applied to Mount Mageik and Trident's fumarolic gas compositions suggest that their hydrothermal reservoirs are located at depths of $\sim 0.2$ and $4 \mathrm{~km}$ below the surface, respectively. Observations of an unusually reducing gas composition at Trident and organic material in the near-surface soils suggest that thermal decomposition of sediments may be influencing gas composition. When the measured gas compositions from Mount Mageik and Trident are compared with previous samples collected in the late 1990's, relatively stable magmatic-hydrothermal conditions are inferred for Mount Mageik, while gradual degassing of residual magma and contamination by shallow crustal fluids is inferred for Trident. The isotopic composition of volcanic gases emitted from Mount Mageik and Trident reflect mixing of subducted slab, mantle and crustal volatile sources, with organic sediment and carbonate being the predominant sources. Considering the close proximity of the target volcanoes in comparison with the depth to the subducted slab we speculate that Aleutian Arc volatiles are fed by a relatively homogeneous subducted fluid and that much of the apparent variability in volatile provenance can be explained by shallow crustal volatile sources and/or processes.
\end{abstract}

(C) 2017 Elsevier B.V. All rights reserved.

\footnotetext{
* Corresponding author at: UAF Geophysical Institute, 903 Koyukuk Drive, Fairbanks, AK 99775, USA.
}

E-mail address: tmlopez@alaska.edu (T. Lopez).

\section{Introduction}

Volatiles (including fluids and gas) are released from arc volcanoes following a complex journey that begins with subduction and ends with surficial outgassing. Physical and chemical processes within the 
subduction cycle modify the chemical and isotopic composition of the cycled volatiles in ways that can often times be deduced using geochemical tools. Within the subduction cycle, fluids that are ultimately released from arc volcanoes can originate from three possible sources: the subducted slab, mantle wedge and crust, each of which has distinct isotopic signatures (Giggenbach, 1982; Giggenbach, 1992a; Sano and Marty, 1995; Fischer et al., 1998; Fischer et al., 2002). By comparing the isotopic composition of sampled volcanic fluids with well-studied reference samples, inferences on volatile provenance can be made (e.g. Giggenbach, 1992a; Symonds et al., 1994; Sano and Marty, 1995; Fischer et al., 1998; Fischer et al., 2002; Zimmer et al., 2004). Similarly, identification of actively degassing magma and constraints on subvolcanic conditions within the mid to shallow crust can be made by comparing the chemical and isotopic composition of measured volcanic fluid discharges with those from other well-studied volcanoes, experimental analogues and/or geochemical models (e.g. Giggenbach, 1987, 1997; Fischer et al., 1998). The composition of recycled and magmatic volatiles can be modified within the shallow crust due to chemical reactions among magmatic fluids, rocks, and hydrothermal systems; mixing with hydrothermal and atmospheric fluids; as well as interaction with biomass (Giggenbach, 1987, 1997; Chiodini and Marini, 1998).

Among the volcanic arcs around the world, the Aleutian Arc is one of the least-studied arcs due to the remote location and relative inaccessibility of the volcanoes, such that volatile cycling within this region is currently poorly constrained. Here we use the chemical and isotopic composition of volcanic gases and steam condensate to constrain volatile sources and characterize subvolcanic conditions at three persistently degassing and seismically active volcanoes within the Katmai Volcanic Cluster, Aleutian Arc, Alaska (Fig. 1). We employ direct and remote sampling techniques including: fumarole sampling (Giggenbach, 1975; Motegrossi et al., 2001), in situ plume measurements using Multiple Component Gas Analyzer System (MultiGAS) instruments (Aiuppa et al., 2005; Shinohara, 2005), and remote sensing of $\mathrm{SO}_{2}$ flux by ultraviolet (UV) spectrometer systems (Galle et al., 2010) to acquire a comprehensive characterization of the degassing systems. Additionally, we build on previous studies (e.g. Symonds et al., 2003a, 2003b) to evaluate changes in the chemical and isotopic composition of these gases over time. Finally, we compare the compositional features from the target volcanoes to other Alaskan volcanoes to make inferences on volatile cycling within the Aleutian Arc.

\section{Geologic setting and volcanic history}

The Katmai Volcanic Cluster (KVC) is located on the Eastern Alaska Peninsula of the Aleutian Arc, $440 \mathrm{~km}$ southwest of Anchorage, Alaska
(Fig. 1). The KVC is home to eight, primarily andesitic to dacitic volcanic centers located over a nearly-linear, arc-parallel $\sim 50 \mathrm{~km}$ distance (Jolly and McNutt, 1999; Hildreth and Fierstein, 2000; Moran, 2003). The KVC volcanoes were built primarily on Jurassic marine sedimentary rocks (e.g. conglomerates, sandstones, siltstones, and shales) of the Naknek Formation, though Eocene age coal-bearing sedimentary rocks are also found scattered throughout this region (Keller and Reiser, 1959). The Katmai region is famous for the 1912 eruption of Novarupta and resulting collapse of Mount Katmai. This was the largest eruption of the 20th century and produced $>13 \mathrm{~km}^{3}$ of erupted material that filled what is now known as the Valley of Ten Thousand Smokes (Hildreth and Fierstein, 2000). In addition to the Katmai/Novarupta eruption of 1912, the 1953-1974 Southwest Trident eruption was the only other historic KVC eruption, which was sourced from a new vent and produced $\sim 0.5 \mathrm{~km}^{3}$ of andesite and dacite lavas and tephra (Coombs et al., 2000). In addition to the significant volcanic activity evident within the KVC, this region is also known for being one of the most seismically active regions of Alaska (Dixon et al., 2013). Much of the Katmai seismicity has been attributed to subsurface fluid flow, including possible magma intrusion, magma degassing, and hydrothermal fluid circulation (Jolly and McNutt, 1999; Moran, 2003; Jolly et al., 2007; O'Brien et al., 2012; Murphy et al., 2014). It is notable that Mount Martin, Mount Mageik and Trident volcanoes have had persistent gas plumes for 100 years (Fig. 2) (Fenner, 1930; Hildreth and Fierstein, 2000; Hildreth et al., 2001; Hildreth and Fierstein, 2012). The combination of high levels of volcanic activity, persistent degassing and evidence for shallow magma storage has made Mount Martin, Mount Mageik and Trident Volcano the targets of this study.

\subsection{Mount Martin}

Mount Martin $\left(58.1692^{\circ} \mathrm{N}, 155.3566^{\circ} \mathrm{W}, 1860 \mathrm{~m}\right)$ is a glaciated andesitic-dacitic stratovolcano located in the southwest of the KVC (Figs. 1, 2) (Hildreth and Fierstein, 2000). Mount Martin's summit cone contains a 300 m diameter, steeply walled crater containing a lake and a vigorously degassing fumarole field (Fig. 2) (Hildreth and Fierstein, 2000). Audible jetting of the active fumaroles can be heard regularly from Baked Mountain ( 16 km away; Fig. 1) and likely indicates relatively high velocity outgassing.

\subsection{Mount Mageik}

Mount Mageik $\left(58.1946^{\circ} \mathrm{N}, 155.2544^{\circ} \mathrm{W}, 2165 \mathrm{~m}\right)$ is an andesitic to dacitic compound stratovolcano comprised of four heavily glaciated summit cones representing different eruptive events (Hildreth and
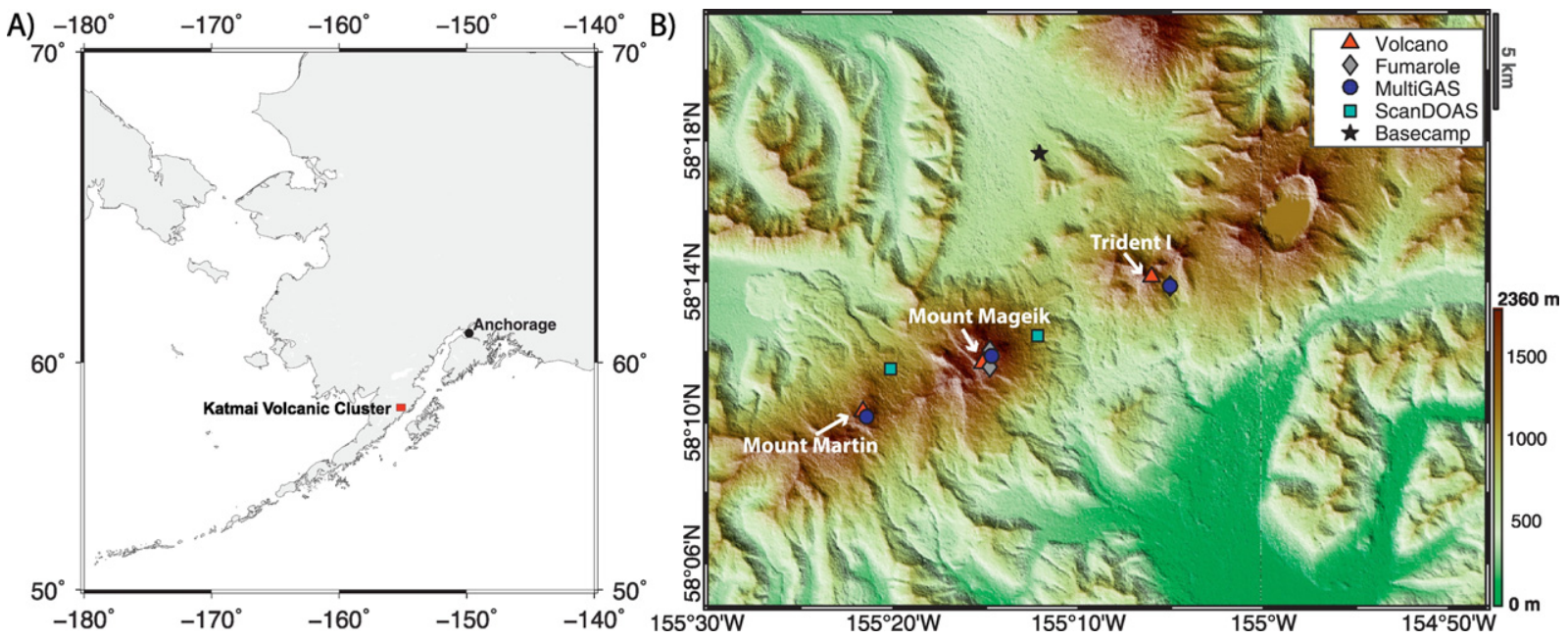

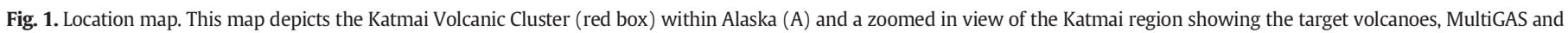
ScanDOAS station locations, sample locations, and basecamp (Baked Mountain) (B). 
Fierstein, 2000). It is located $\sim 7 \mathrm{~km}$ northeast of Mount Martin, $10 \mathrm{~km}$ southwest of Trident Volcano, and is immediately adjacent to Katmai Pass (Fig. 1). Its summit hosts a 350 m diameter phreatic crater, that contains an acidic crater lake and actively degassing fumarole field (Fig. 2) (Hildreth and Fierstein, 2000).

\subsection{Trident Volcano}

Trident Volcano $\left(58.2343^{\circ} \mathrm{N}, 155.1026^{\circ} \mathrm{W}, 1097 \mathrm{~m}\right)$ is located $\sim 10 \mathrm{~km}$ NE of Mount Mageik. It is an andesitic to dacitic compound stratovolcano, comprised of four overlapping edifices: East Trident, Trident I, West Trident and Southwest (i.e. New) Trident (Fig. 1), as well as several adjacent domes (Hildreth and Fierstein, 2000). Trident is the home of the most recent KVC eruption between 1952 and 1974. An active fumarole field is located on the southeast flank of the Trident I edifice.

\section{Methods}

A field campaign was conducted within Katmai National Park from 10-22 July 2013. During this time period the following objectives were met: (1) fumarolic gases and steam condensates were directly sampled from Mount Mageik and Trident Volcano; (2) MultiGAS instruments were installed on the crater rims of Mount Martin and Mount Mageik and adjacent to the Trident I fumarole field to measure major species plume composition, and (3) scanning ultraviolet (UV) spectrometer systems were deployed downwind from Mount Martin and Mount Mageik to measure $\mathrm{SO}_{2}$ flux. These are the first fumarole samples collected at these volcanoes in $\sim 15$ years, with prior fumarole samples collected from Trident and Mount Mageik between 1995 and 1998 by Symonds et al. (2003a). Additionally, several airborne plume measurements were made by USGS scientists at Mount Martin and Mount Mageik between 2002-2006 (Doukas and McGee, 2007), which provide some baseline volcanic emissions data at these volcanoes.

\subsection{Fumarole sampling methods}

During the field campaign, fumaroles were sampled from Mount Mageik's north crater fumarole field and Trident I's southeast (SE) fumarole field (Figs. 1, 2; Table 1). Unfortunately, safe access to the vigorously degassing fumarole field within Mount Martin's steeply-walled crater was not possible, such that no direct samples of Mount Martin's fumaroles were acquired. In each case, fumarole samples were collected for analyses of: (1) gas chemical composition, (2) $\mathrm{O}_{2}$ and D stable isotopes of water vapor, and (3) $\delta^{13} \mathrm{C}_{\text {of }} \mathrm{CO}_{2}, \mathrm{CH}_{4}, \mathrm{C}_{2} \mathrm{H}_{6}$ and $\mathrm{C}_{3} \mathrm{H}_{8} ; \delta^{15} \mathrm{~N}$ of $\mathrm{N}_{2}$; and ${ }^{4} \mathrm{He} /{ }^{20} \mathrm{Ne}$ and ${ }^{3} \mathrm{He} /{ }^{4} \mathrm{He}$ ratios. During the sampling procedure, a titanium tube was inserted into the fumarolic vent and allowed to thermally equilibrate with the fumarolic gases. Then, a series of dewared Pyrex glass tubes were connected to modified Giggenbachtype flasks (Giggenbach, 1975) consisting of pre-weighed $50 \mathrm{~mL}$ evacuated bottles, each containing $20 \mathrm{~mL}$ of an $0.15 \mathrm{M} \mathrm{Cd}(\mathrm{OH})_{2}$ and $4 \mathrm{M} \mathrm{NaOH}$ suspension to enable quantification of both $\mathrm{SO}_{2}$ and $\mathrm{H}_{2} \mathrm{~S}$, in addition to the major and trace gas species following the methods of Motegrossi et al. (2001). According to this method, the non-condensable gases $\mathrm{N}_{2}$, $\mathrm{Ar}, \mathrm{O}_{2}, \mathrm{H}_{2}, \mathrm{He}, \mathrm{CO}, \mathrm{Ne}, \mathrm{CH}_{4}$ fill the bottle's head-space, the reactive gases $\mathrm{CO}_{2}, \mathrm{SO}_{2}, \mathrm{HCl}, \mathrm{HF}$ and $\mathrm{NH}_{3}$ are absorbed into the $\mathrm{NaOH}$ solution, $\mathrm{H}_{2} \mathrm{~S}$ reacts with $\mathrm{Cd}^{2+}$ to precipitate solid $\mathrm{CdS}$, and water condenses. Among the head-space gases, the inorganic gases were analyzed by gas chromatography (GC) following the methods of Motegrossi et al. (2001). Volatile organic compounds, including $\mathrm{CH}_{4}$, were analyzed by GC using a Shimadzu 14A instrument equipped with a flame ionization detector (FID) and a 10-m-long stainless steel column packed with Chromosorb PAW 80/100 mesh coated with 23\% SP 1700. The analytical error for GC analysis was $<5 \%$. The liquid and solid phases were separated by centrifugation and divided into sample aliquots. The solid $\mathrm{CdS}$, representing $\mathrm{H}_{2} \mathrm{~S}$ gas, and an aliquot of liquid, containing absorbed $\mathrm{SO}_{2}$ gas, were each oxidized using $\mathrm{H}_{2} \mathrm{O}_{2}$ to form $\mathrm{SO}_{4}^{2-}$ in solution,

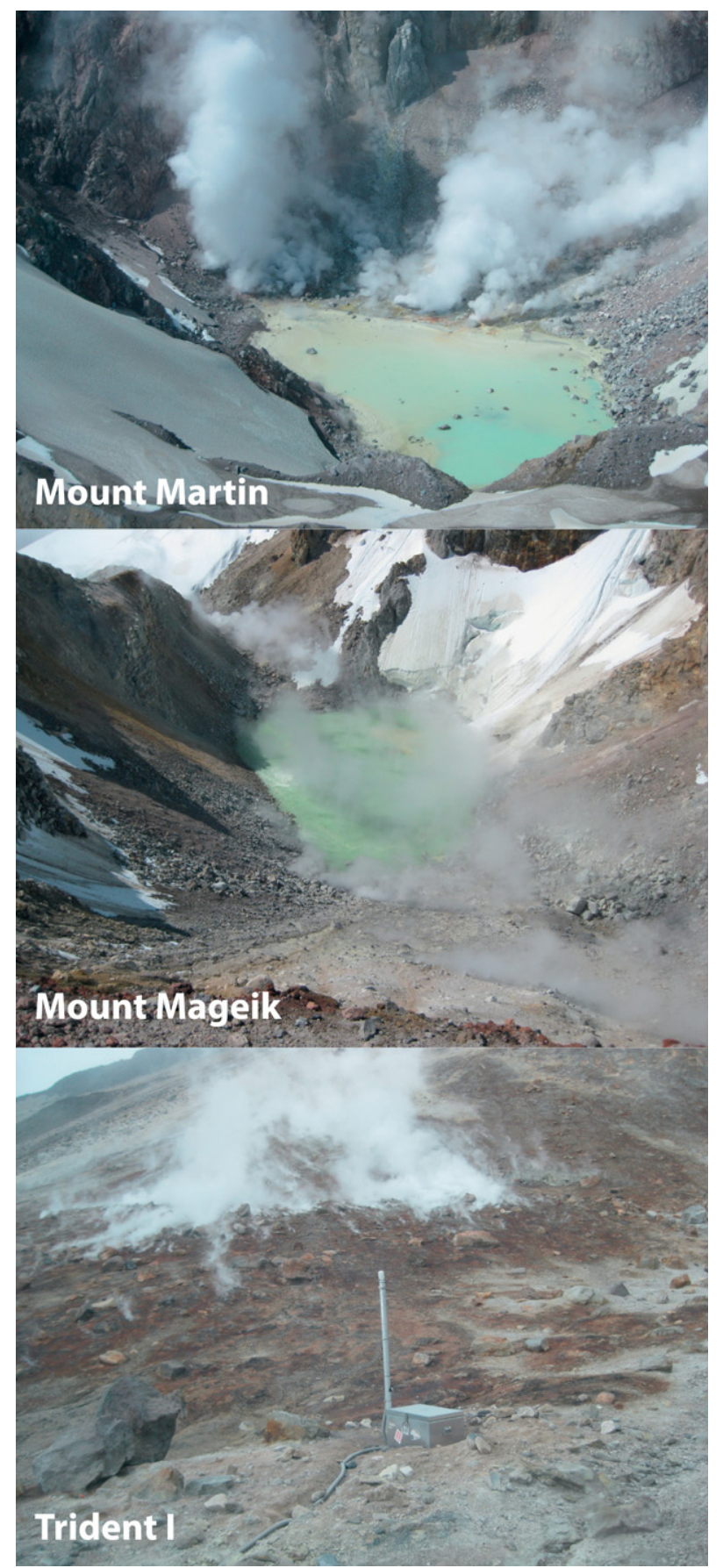

Fig. 2. Degassing manifestation of the target volcanoes. Mount Martin (top), Mount Mageik (center), and Trident (I) (bottom) are shown. The Trident MultiGAS station is seen in the foreground in the bottom photo.

which were then analyzed using a 761 Compact Metrohm ion chromatograph (IC). $\mathrm{CO}_{2}$ was quantified as $\mathrm{CO}_{3}^{2-}$ by acidimetric titration (AT; Metrohm Basic Titrino 794), while $\mathrm{HCl}$ was quantified as $\mathrm{Cl}^{-}$by ion chromatography with the same IC used for the analysis of $\mathrm{SO}_{4}^{2-}$. $\mathrm{H}_{2} \mathrm{O}$ concentration was calculated using the sample mass difference and subtracting the mass of absorbed gases. All major and trace gas analyses described above were conducted at the Fluid Geochemistry Laboratory at the University of Florence (Italy).

The analysis of the ${ }^{13} \mathrm{C} /{ }^{12} \mathrm{C}$ ratio of $\mathrm{CH}_{4}, \mathrm{C}_{2} \mathrm{H}_{6}, \mathrm{C}_{3} \mathrm{H}_{8}$ and $\mathrm{C}_{4} \mathrm{H}_{10}\left(\delta^{13} \mathrm{C}\right.$ $\mathrm{CH}_{4}, \delta^{13} \mathrm{C}-\mathrm{C}_{2} \mathrm{H}_{6}, \delta^{13} \mathrm{C}-\mathrm{C}_{3} \mathrm{H}_{8}$ and $\delta^{13} \mathrm{C}-\mathrm{C}_{4} \mathrm{H}_{10}$, respectively, expressed as \%。 vs. V-PDB) were carried out at the Goethe University in Frankfurt following the methods of Fiebig et al. (2015). External analytical precision 
Table 1

Instrument deployment and sample sites.

\begin{tabular}{|c|c|c|c|c|c|c|c|c|c|}
\hline \multicolumn{10}{|c|}{ A) Instrument installations: } \\
\hline Instrument ID & Instrument & Volcano & Date installed & Latitude & Longitude & Altitude $(\mathrm{m})$ & Date sampling ceased & Site description & Sample frequency \\
\hline MGK_MG & MultiGas & Mageik & $7 / 12 / 2013$ & 58.19775 & 155.24475 & 1986 & $7 / 22 / 2013$ & NE Crater Rim & $4 \times 30$ min per day \\
\hline MGK_DOAS & DOAS & Mageik & $7 / 12 / 2013$ & 58.20788 & 155.20357 & 1184 & NA & E Flank Lava Levee & Continuously - daylight \\
\hline MRTN_MG & MultiGas & Martin & $7 / 13 / 2013$ & 58.16941 & 155.35658 & 1829 & $8 / 13 / 2013$ & North Crater Rim & $4 \times 30$ min per day \\
\hline MRTN_DOAS & DOAS & Martin & $7 / 13 / 2013$ & 58.19194 & 155.33517 & 1177 & NA & NE Moraine & Continuously - daylight \\
\hline TRI_MG & MultiGas & Trident I - SE flank & $7 / 17 / 2013$ & 58.23149 & 155.0835 & 1135 & $8 / 27 / 2013$ & SE Fumarole Field & $4 \times 30$ min per day \\
\hline
\end{tabular}

B) Gas samples:

\begin{tabular}{|c|c|c|c|c|c|c|c|}
\hline Sample ID & Sample type & Volcano & Sample date & Latitude & Longitude & Altitude (m) & Temp (deg C) \\
\hline MGK_Fum_1 & Fumarole & Mageik & $7 / 12 / 2013$ & 58.20081 & 155.24684 & 1912 & 92 \\
\hline MGK_Fum_2 & Fumarole & Mageik & $7 / 12 / 2013$ & 58.19316 & 155.24650 & 1912 & 93 \\
\hline TRI_Fum_1 & Fumarole & Trident I - SE flank & $7 / 16 / 2013$ & 58.23131 & 155.08412 & 1159 & 94 \\
\hline TRI_Fum_2 & Fumarole & Trident I - SE flank & $7 / 16 / 2013$ & 58.23141 & 155.08507 & 1203 & 97 \\
\hline
\end{tabular}

C) Water samples:

\begin{tabular}{|c|c|c|c|c|c|c|c|c|c|}
\hline Sample ID & Sample type & Location & Sample date & Latitude & Longitude & Altitude (m) & Temp $(\operatorname{deg} C)$ & $\mathrm{pH}$ & Conductivity $(\mu \mathrm{S} / \mathrm{cm})$ \\
\hline MGK_Lake & Water & Mageik Crater Lake & $7 / 12 / 2013$ & 58.19658 & 155.24596 & 1888 & 72.3 & 0.55 & Not measured \\
\hline Rain Water & Water & Baked Mtn Huts & $7 / 17 / 2013$ & 58.29353 & 155.20155 & 781 & 15 & 6.22 & 9.99 \\
\hline
\end{tabular}

for carbon isotope analysis of methane, ethane and propane was $\pm 0.5 \%$.

The $\delta^{15} \mathrm{~N}$ ratios of $\mathrm{N}_{2}$ (expressed as \% vs. air) and ${ }^{40} \mathrm{Ar} /{ }^{36} \mathrm{Ar}$ ratios in the flask headspace gas were determined at the Istituto Nazionale di Geofisica e Vulcanologia (INGV) laboratories of Naples (Italy) using an Agilent 6890 N GC coupled with a Finnigan Delta plusXP continuousflow MS, equipped with a molecular sieve column (MS 5 Å capillary, $30 \mathrm{~m} \times 0.53 \mathrm{~mm} \times 50 \mu \mathrm{m}$; He carrier gas), a TCD detector and a post-column switching device (Denswitch), following the methods of Caliro et al. (2015). Analytical errors were: $\delta^{15} \mathrm{~N} \pm 0.1 \%$, ${ }^{36} \mathrm{Ar}<1 \%,{ }^{40} \mathrm{Ar}<3 \%$. The ${ }^{34} \mathrm{~S} /{ }^{32} \mathrm{~S}$ ratios of $\mathrm{H}_{2} \mathrm{~S}\left(\delta^{34} \mathrm{~S}-\mathrm{H}_{2} \mathrm{~S}\right.$, expressed as \% vs. V-CDT) were analyzed at the ISO4 laboratories at Turin (Italy) on $\mathrm{SO}_{4}^{2-}$ obtained from oxidation (with $\mathrm{H}_{2} \mathrm{O}_{2}$ ) of an aliquot of the $\mathrm{CdS}$ precipitate using an EAIRMS system consisting of a 20-20 isotope ratio mass spectrometer (Europa Scientific, Crewe, UK), equipped with an elemental analyzer (Sercon Ltd., Crewe, UK). The analytical uncertainty was $\pm 0.3 \%$.

At each sampling site, a water-cooled condenser was connected to the sampling line in order to collect a steam condensate aliquot $(\sim 100 \mathrm{~mL})$ and a dry gas sample in double valve sample bottles following the methods of Vaselli et al. (2006). The dry gas samples were used for the analysis of $\mathrm{CO}$ concentrations by means of gas-chromatographic separation with a GC equipped with a high-sensitivity (detection limit $0.05 \mathrm{ppm}$ ) reduced gas $(\mathrm{HgO})$ detector and a molecular sieve $5 \mathrm{~A} 1 / 8^{\prime}$ $\times 50$ ' column (He as gas carrier). CO cannot be accurately quantified using the gas in the soda flask headspace due to the conversion of $\mathrm{CO}$ to formate ion $\left(\mathrm{HCOO}^{-}\right.$) (Giggenbach and Matsuo, 1991).

At the INGV-Palermo Noble Gas Isotopes Laboratory, the dry gas samples were also analyzed for ${ }^{3} \mathrm{He} /{ }^{4} \mathrm{He}$ and ${ }^{4} \mathrm{He} /{ }^{20} \mathrm{Ne}$ ratios using a Helix SFT-GVI mass spectrometer, following the purification procedure described in Rizzo et al. (2015) and references therein. The ${ }^{3} \mathrm{He} /{ }^{4} \mathrm{He}$ ratios (expressed as $\mathrm{R} / \mathrm{R}_{\mathrm{A}}$, where $\mathrm{R}$ is the ${ }^{3} \mathrm{He} /{ }^{4} \mathrm{He}$ measured in the sample and $\mathrm{R}_{\mathrm{A}}$ is the ${ }^{3} \mathrm{He} /{ }^{4} \mathrm{He}$ ratio in air $\left(1.39 \times 10^{-6}\right)$ (Mamyrin and Tolstikhin, 1984) were corrected for atmospheric contamination using the ${ }^{4} \mathrm{He} /{ }^{20} \mathrm{Ne}$ ratios (Poreda and Craig, 1989), and reported hereafter as $\mathrm{R}_{\mathrm{C}} / \mathrm{R}_{\mathrm{A}}$. The analysis of ${ }^{13} \mathrm{C} /{ }^{12} \mathrm{C}$ of $\mathrm{CO}_{2}$ (expressed as $\delta{ }^{13} \mathrm{C}_{-} \mathrm{CO}_{2} \%$ 。 vs. V-PDB) was carried out at the CNR-IGG laboratories (Pisa, Italy) using a Finningan Delta $\mathrm{S}$ mass spectrometer after standard extraction and purification procedures of the gas mixtures (Evans et al., 1998; Vaselli et al., 2006). Carrara and San Vincenzo marbles (Internal), as well as NBS18 and NBS19 (International) standards were used to estimate the external precision. The analytical error was $\pm 0.05 \%$ and $\pm 0.1 \%$, respectively.

At the Fluid Geochemistry Laboratory at the University of Florence, $\mathrm{HF}$ was quantified as $\mathrm{F}^{-}$in the condensate samples by IC, whereas the analysis of $\mathrm{NH}_{3}\left(\right.$ as $\left.\mathrm{NH}_{4}^{+}\right)$was carried out by potentiometry with specific electrode. The $\delta^{18} \mathrm{O}$ and $\delta \mathrm{D}$ isotopes of $\mathrm{H}_{2} \mathrm{O}$ (expressed as \% vs. VSMOW) were analyzed at the INGV-Naples Geochemistry Laboratory using a Finningan Delta plusXP continuous-flow MS coupled with GBII, using equilibration techniques with $\mathrm{CO}_{2}$ for oxygen (Epstein and Mayeda, 1953), and with $\mathrm{H}_{2}$ for hydrogen (Nelson, 2000; Chiodini et al., 2012). Analytical errors were: $\delta \mathrm{D} \pm 1 \%$, $\delta^{18} \mathrm{O} \pm 0.08 \%$.

\subsection{MultiGAS measurements of plume composition}

Campaign MultiGAS instruments (Aiuppa et al., 2005) were deployed on the crater rims of Mount Mageik and Mount Martin in the dominant downwind direction, and adjacent to Trident I's southeast fumarole field (Figs. 1, 2; Table 1). These instruments each contain a Gas Card infrared $\mathrm{CO}_{2}$ analyzer, City Tech $\mathrm{SO}_{2}$ and $\mathrm{H}_{2} \mathrm{~S}$ electrochemical sensors, as well as temperature $(\mathrm{T})$, pressure $(\mathrm{P})$, and relative humidity $(\mathrm{RH})$ sensors. The instruments and their batteries were contained within weather-resistant aluminum enclosures, with inlet/outlet ports to provide access to ambient air. During operation, plume gas was pumped into the instrument at $\sim 1 \mathrm{~L} / \mathrm{min}$ and analyzed by each sensor in series. In the case of the higher-altitude stations at Mount Mageik and Mount Martin, small electrical heaters were installed within the inlet and outlet ports to prevent icing. The instruments were configured to collect measurements of reference (plume-free) air (for an $\sim 5$ min sample period) and plume air (for an $\sim 25 \mathrm{~min}$ sample period) at a $0.1 \mathrm{~Hz}$ sample rate for four thirty-minute periods each day, for approximately one month. The mixing ratio (ppmv) of each measured species, T, P and RH were recorded on an internal data logger and stored onsite.

MultiGAS data were analyzed following the methods of Aiuppa et al. (2010, 2012, 2014), Tamburello (2015) and Tamburello et al. (2015). First, electrochemical sensor data were corrected for temperature and pressure using the Ideal Gas Law and the measured atmospheric parameters ( $\mathrm{T}, \mathrm{P}, \mathrm{RH}) . \mathrm{H}_{2} \mathrm{O}$ mixing ratios were calculated using measurements of T, P and RH and the Arden Buck equation (Tamburello, 2015). Crosssensitivity effects of $\mathrm{H}_{2} \mathrm{~S}$ on the $\mathrm{SO}_{2}$ sensor and vice versa were measured in the lab prior to deployment and corrected values were calculated; however because the measured $\mathrm{SO}_{2} / \mathrm{H}_{2} \mathrm{~S}$ was $\ll 1$ at each site, and because no interference effects were observed in the data, non-interference-corrected values were used in the following analyses. Minimum values in each dataset were assumed to represent ambient air and were subtracted to get baseline-corrected values. Additionally, effects of instrument drift, which were commonly observed for $\mathrm{H}_{2} \mathrm{O}$, and at times $\mathrm{CO}_{2}$, were removed from these datasets through manual selection of baseline values for each sample period using RatioCalc software 
(Tamburello, 2015). Because varying wind directions modified the proportion of plume vs. atmospheric gases measured by the instrument, $\mathrm{H}_{2} \mathrm{~S}$ values greater than a threshold value were used to identify periods when the plume was detected. Threshold values were selected based on the maximum observed noise level for each of the three $\mathrm{H}_{2} \mathrm{~S}$ sensors, with threshold values of $\mathrm{H}_{2} \mathrm{~S}>1,1.5$, and 4 ppmv used at Mount Martin, Mount Mageik and Trident Volcano, respectively. Changes in gas composition were evaluated over time, and linear correlations between measured parameters were evaluated for each sample period as well for the full dataset using Matlab and RatioCalc analyses software. All ratios were calculated with respect to $\mathrm{H}_{2} \mathrm{~S}$, the main volcanic gas tracer.

\subsection{DOAS measurements of $\mathrm{SO}_{2}$ flux}

Campaign continuously scanning DOAS instruments (Galle et al., 2010) were deployed $\sim 2.8 \mathrm{~km} \mathrm{NE}$ (in the dominant down-wind direction) of both Mount Martin and Mount Mageik. These instruments use scattered UV radiation and Differential Optical Absorption Spectroscopy (DOAS) principles (Platt and Stutz, 2008) to convert measured absorbance by $\mathrm{SO}_{2}$ into $\mathrm{SO}_{2}$ slant column density (Galle et al., 2002; Edmonds et al., 2003; Galle et al., 2010). A series of these measurements are collected in a conical arc across the overhead sky containing the plume to provide an $\mathrm{SO}_{2}$ column density cross-section, which can then be integrated over plume width and multiplied by plume speed to calculate $\mathrm{SO}_{2}$ flux ( $\mathrm{t} / \mathrm{d}$ or $\mathrm{kg} / \mathrm{s}$ ). Plume width was calculated trigonometrically using an assumed plume height equivalent to the crater rim altitude at Mount Martin (550 m above instrument altitude) and Mount Mageik (750 $\mathrm{m}$ above instrument altitude), and the angular plume scan measurements by the DOAS instrument. These plume altitudes are consistent with our visual observations during the field campaign and supported by frequent detection of volcanic gases by the crater rim MultiGAS instruments. Plume speed was determined either from modeled wind data from National Oceanic and Atmospheric Administration (NOAA) or European Center for Medium-Range Weather Forecasts (Galle et al., 2010), or helicopter-based measurements of GPS wind-drift following the methods of Doukas (2002). The DOAS instruments employed at Mount Martin and Mount Mageik were modified from the standard model described in Galle et al. (2010) in order to improve performance at high-latitudes, considering the frequent harsh-environmental conditions and low angle solar radiation. Specifically, a more UV sensitive MayaPro2000 spectrometer replaced the standard Ocean Optics S2000 + spectrometer, and a closed scanner with a cylindrical quartz tube replaced the rotating hood with window. Additionally, a cylindrical lens was implemented in the optical system that resulted in a rectangular FOV covering a $7.2^{\circ}$ angle for each measurement interval to maximize coverage of the volcanic plume. Using a fixed exposure time of $150 \mathrm{~ms}$ and co-adding 15 spectra resulted in a total scan duration of $2 \mathrm{~min}$. Although useful measurements could only be obtained between approximately 09:00 and 19:00 (local time), the instrument was powered $\sim 24 \mathrm{~h}$ per day to prevent condensation in the closed scanner compartment. Scanning data were first evaluated to identify periods during which: (1) at least $70 \%$ of the plume was sampled in individual scans, and (2) measurements were collected within five hours of solar noon (9:00 and 19:00 local time), which provided sufficient $\mathrm{UV}$ radiation to minimize error in $\mathrm{SO}_{2}$ column density to $\leq 5 \mathrm{ppmm}$, with error calculated as spectral residual peak-to-peak size scaled with the $\mathrm{SO}_{2}$ absorption cross-section (Platt and Stutz, 2008). Additional details on the DOAS analyses methods are described in Galle et al. (2010).

In addition to the continuously scanning ground-based DOAS instruments, airborne mobile-DOAS measurements were made at Mount Martin and Mount Mageik on 15 July by flying circular orbits around the target volcanoes and below the plume to measure vertical $\mathrm{SO}_{2}$ column densities. A total of two and three measurement orbits were made around Mount Mageik and Mount Martin, respectively, between
16:23 and 16:58 local time (00:23-00:58 UTC on July 16). Additionally, three "wind circle" GPS orbits were made up wind of Mount Martin, at plume altitude, and with constant speed and turn of the helicopter, in order to determine plume speed and direction following the methods of Doukas (2002). The total flight path is shown in Fig. 3, where the color bar scale indicates total measured $\mathrm{SO}_{2}$ column density (ppmm) above the instrument, where $1 \mathrm{ppmm}=2.85 \times 10^{-5} \mathrm{~kg} / \mathrm{m}^{2}$ (Gerlach, 2003).

\section{Results}

\subsection{Chemical and isotopic composition of fumarolic gases}

\subsubsection{Mount Mageik}

Fumarole and steam condensate samples were collected from two fumaroles on the north crater wall of Mount Mageik on 12 July 2013 (Fig. 1, Table 1). The measured outlet fumarole temperatures were both $\sim 93^{\circ} \mathrm{C}$, which is boiling point at the sample altitude. The $\mathrm{pH}$ and temperature of the crater lake were measured at 0.55 and $72.3^{\circ} \mathrm{C}$, respectively. The chemical composition of the Mount Mageik gases was largely composed of $\mathrm{H}_{2} \mathrm{O}$ ( $\left.\sim 97 \mathrm{~mol} \%\right), \mathrm{CO}_{2}$ ( $\left.\sim 3 \mathrm{~mol} \%\right), \mathrm{H}_{2} \mathrm{~S}(0.12 \mathrm{~mol} \%)$ and $\mathrm{N}_{2}(0.09-0.13-\mathrm{mol} \%)$ (Table 2$)$. The acid volcanic gas species were absent (e.g. $\mathrm{SO}_{2}$ ) and/or present in very minor quantitates (e.g. $\mathrm{HCl} \sim 2$ $\times 10^{-5} \mathrm{~mol} \%$ ). The composition of low solubility inorganic gases was dominated by $\mathrm{N}_{2}$ (up to $0.13 \mathrm{~mol} \%$ ) and $\mathrm{H}_{2}$ (0.013 and $0.016 \mathrm{~mol} \%$ ), whereas $\mathrm{O}_{2}$, Ar, Ne, He and $\mathrm{CO}$ show minor concentrations (up to $0.0061,0.0011,7.5 \times 10^{-5}, 3.3 \times 10^{-5}$, and $8.3 \times 10^{-6} \mathrm{~mol} \%$, respectively). Methane was by far the most abundant organic gas compound (0.00072 and $0.00097 \mathrm{~mol} \%$ ) (Table 2).

The $\delta \mathrm{D}$ and $\delta^{18} \mathrm{O}$ of $\mathrm{H}_{2} \mathrm{O}$ from Mount Mageik's steam condensate ranged from -85.4 to $-90.1 \%$ and -5.0 to $-5.7 \%$ ovs. V-SMOW, respectively. The $\mathrm{Cl}$ content in the condensate ranged from 0.09 to $0.2 \mathrm{mg} / \mathrm{L}$. Only one measurement of ${ }^{3} \mathrm{He} /{ }^{4} \mathrm{He}$ was obtained which gives a value of $7.40 \mathrm{R}_{\mathrm{A}}$. Using the measured ${ }^{4} \mathrm{He} /{ }^{20} \mathrm{Ne}$ ratio of 13.5 , we calculate an $\mathrm{R}_{\mathrm{C}} / \mathrm{R}_{\mathrm{A}}$ of 7.56 (Table 4$)$. The $\delta^{13} \mathrm{C}^{-} \mathrm{CO}_{2}$ values $(-8.6$ and $-8.9 \%$ v vs. V-PDB) were slightly depleted with respect to mantlerelated fluids ([from -8 to $-3 \%$ vs. V-PDB; Pineau and Javoy, 1983; Javoy et al., 1986; Hoefs, 1997). The $\delta^{15} \mathrm{~N}-\mathrm{N}_{2}$ values were 0.6 and $-0.02 \%$ vs. air, whereas the $\delta^{34} \mathrm{~S}-\mathrm{H}_{2} \mathrm{~S}$ values were -1.5 and $-1.8 \%$ 。 vs. V-CDT (Table 3). These data are available in the EarthChem Library (Lopez et al., 2017).

\subsubsection{Trident Volcano}

Fumarole and steam condensate samples were collected from two fumaroles within the southeast fumarole field on the flank of Trident I on 16 July 2013 (Fig. 1, Table 1). The outlet fumarole temperatures were 94 and $97^{\circ} \mathrm{C}$, i.e. near boiling point temperature at the sample altitude $\left(\sim 96{ }^{\circ} \mathrm{C}\right)$. The Trident fumarolic emissions were composed primarily of $\mathrm{H}_{2} \mathrm{O}$ ( 92 mol\%), $\mathrm{CO}_{2}$ ( $\left.\sim 6 \mathrm{~mol} \%\right), \mathrm{H}_{2}(0.86-0.97 \mathrm{~mol} \%), \mathrm{H}_{2} \mathrm{~S}$ (0.49-0.55 $\mathrm{mol} \%), \mathrm{CH}_{4}(0.13-0.19 \mathrm{~mol} \%), \mathrm{N}_{2}(\sim 0.06-0.07 \mathrm{~mol} \%)$ and $\mathrm{CO}$ (0.0038-0.0040 mol\%) (Table 2). Acid gases were absent or present in low quantity, with $\mathrm{SO}_{2}$ below detection limit, and $\mathrm{HCl}$ a minor component $\left(\sim 1.3 \times 10^{-4} \mathrm{~mol} \%\right)$. Following $\mathrm{CH}_{4}$, the next most abundant hydrocarbons measured at Trident were $\mathrm{C}_{2} \mathrm{H}_{6}(0.015-0.023 \mathrm{~mol} \%)$, and $\mathrm{C}_{3} \mathrm{H}_{8}$ (0.0029-0.0048 mol\%).

The $\delta \mathrm{D}$ and $\delta^{18} \mathrm{O}$ of $\mathrm{H}_{2} \mathrm{O}$ values from Trident's steam condensate ranged from -71.3 to $-76.4 \%$ and -2.8 to $-3.8 \%$ vs. V-SMOW, respectively. The $\mathrm{Cl}$ content of in the condensate was $\sim 0.1 \mathrm{mg} / \mathrm{L}$. The R/ $\mathrm{R}_{\mathrm{A}}$ values of 7.0 and 7.1 , and ${ }^{4} \mathrm{He} /{ }^{20} \mathrm{Ne}$ ratios of 8.9 and 9.6 measured in the dry gas samples, yield $R_{C} / R_{A}$ values of 7.2 and 7.3 , respectively. The $\delta^{15} \mathrm{~N}$ values were 3.5 and $3.2 \%$ ov. air, suggesting a minimal atmospheric contribution to the sampled gases. The $\delta^{13} \mathrm{C}$ of $\mathrm{CO}_{2}$ values were -10.9 and $-11.1 \%$ V-PDB, while the $\delta^{34} \mathrm{~S}$ of $\mathrm{H}_{2} \mathrm{~S}$ values ranged from 2.2 to $2.4 \%$ ov. V-CDT (Table 3; Lopez et al., 2017). 
A)

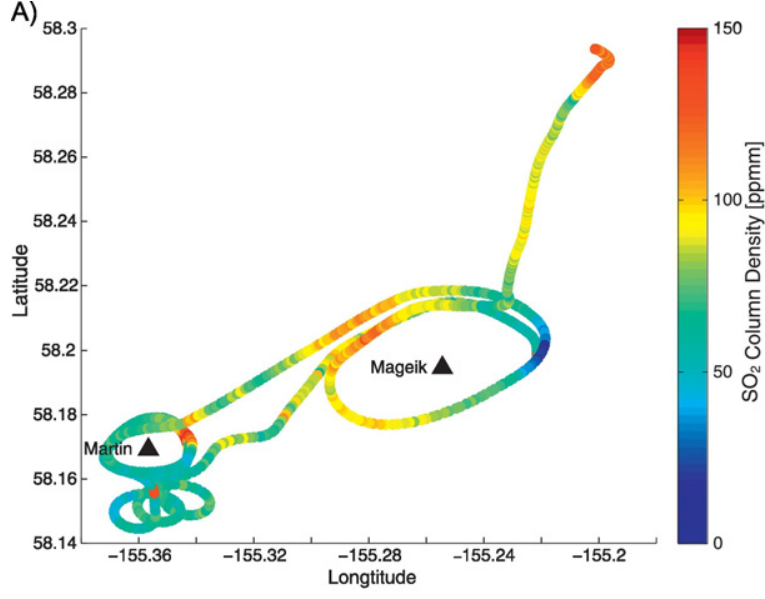

B)

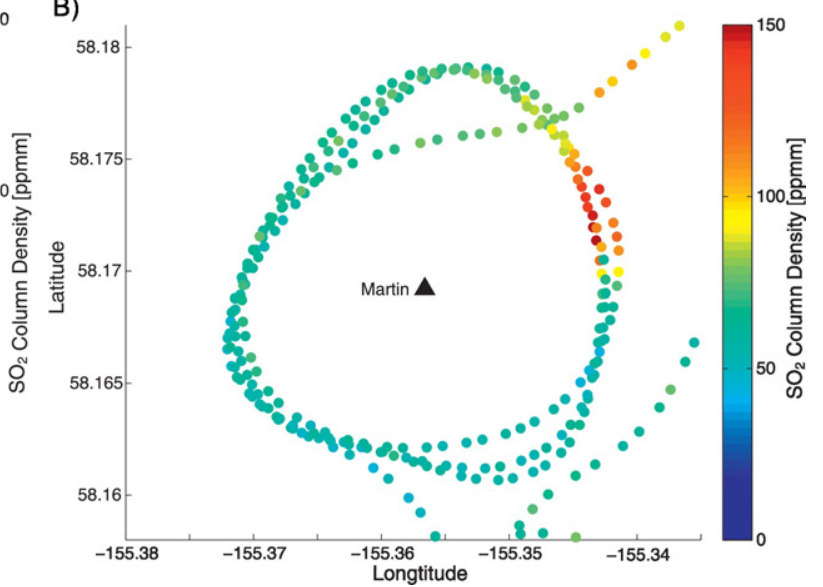

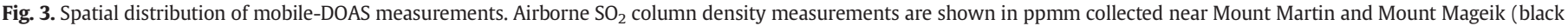
triangles) on July 15, 2013 (A), and a zoomed in view of the measurements at Mount Martin (B).

\subsection{MultiGAS measurements of gas composition}

\subsubsection{Mount Martin}

The Mount Martin MultiGAS instrument collected measurements from 14 July through 13 August 2013, resulting in 31 days of data acquired (Table 1). Based on measured $\mathrm{H}_{2} \mathrm{~S}$ concentrations, we find 19 days during the sample period when the instrument was measuring the volcanic plume and not ambient air. The measured plume was composed of $\mathrm{H}_{2} \mathrm{O}, \mathrm{CO}_{2}, \mathrm{H}_{2} \mathrm{~S}$, and $\mathrm{SO}_{2}$. During this study, linear correlations were consistently observed between $\mathrm{SO}_{2} / \mathrm{H}_{2} \mathrm{~S}$ with molar ratios ranging from 0.2-0.6 (Table 5). Linear correlations were also occasionally observed among other gas species, with $\mathrm{CO}_{2} / \mathrm{H}_{2} \mathrm{~S}$ ratios ranging from 1.7-3.7 on five days and $\mathrm{H}_{2} \mathrm{O} / \mathrm{H}_{2} \mathrm{~S}$ ratios ranging from 351-366 on two days (Fig. 4; Table 4).

\subsubsection{Mount Mageik}

MultiGAS measurements from Mount Mageik's crater rim were acquired between 13 and 21 July 2013 UTC. Unfortunately, challenging environmental conditions (e.g. icing of the inlet) likely contributed to only nine days of data being collected at this site. Based on measured $\mathrm{H}_{2} \mathrm{~S}$ concentrations the plume was measured on six days during the sample period. The measured plume was composed primarily of $\mathrm{H}_{2} \mathrm{O}$, $\mathrm{CO}_{2}, \mathrm{H}_{2} \mathrm{~S}$, and $\mathrm{H}_{2}$, with no $\mathrm{SO}_{2}$ detected. Over the study period, a consistent linear correlation was observed between $\mathrm{CO}_{2}$ and $\mathrm{H}_{2} \mathrm{~S}$ with a molar $\mathrm{CO}_{2} / \mathrm{H}_{2} \mathrm{~S}$ ratio ranging from of 6-9.5 (Fig. 4; Table 5). Additionally, on 13 and 14 July, linear correlations were observed between $\mathrm{H}_{2} \mathrm{O} / \mathrm{H}_{2} \mathrm{~S}$ with ratios of 114 and 118 , respectively.

\subsubsection{Trident Volcano}

The Trident MultiGAS instrument successfully acquired plume measurements for 41 days between 18 July and 27 August 2013 (UTC). The close proximity of the instrument and the plume resulted in acquisition of plume measurements on all days during the study period. During this study period a linear correlation was consistently observed between $\mathrm{CO}_{2} / \mathrm{H}_{2} \mathrm{~S}$ with values ranging from 10.3-11.3 (Fig. 4; Table 4). A linear correlation between $\mathrm{H}_{2} \mathrm{O} / \mathrm{H}_{2} \mathrm{~S}$ was also observed on one day during the study period ( $23 \mathrm{July}$ ) with a value of 88.6. $\mathrm{SO}_{2}$ concentrations were around or below detection limit for the duration of the field campaign.

\section{3. $\mathrm{SO}_{2}$ and total volatile flux}

\subsubsection{Scanning DOAS measurements from Mount Martin and Mount Mageik \\ Scanning DOAS measurements were acquired from 13-28 July and} 13-25 July at Mount Mageik and Mount Martin, respectively.
Unfortunately, unforeseen voltage limitations of the recycled batteries prevented operation for the full sample period, and due to variable wind directions during the sample period, only one day resulted in high quality data acquired that allowed calculation of $\mathrm{SO}_{2}$ fluxes from Mount Martin. Additionally, $\mathrm{SO}_{2}$ emissions were not detected from Mount Mageik throughout the entire measurement period, which is consistent with other results suggesting minimal (below detection limit) quantities of $\mathrm{SO}_{2}$ outgassed. The only day in which plume direction and sampling conditions permitted high quality scanning DOAS measurements of Mount Martin's plume to be made was 15 July 2013. These data were evaluated using a plume height of $550 \mathrm{~m}$ (the height of the crater rim above the instrument, consistent with visual observations), a plume direction of $195^{\circ}$ and a plume speed of $6 \mathrm{~m} / \mathrm{s}$ (see Section 4.3.2). Of the total 1545 scans made on 15 July, only 357 scans met the required plume completeness and time of day requirements. These data resulted in an average plume completeness of 0.77 and an average $\mathrm{SO}_{2}$ flux of $71 \pm 24 \mathrm{t} / \mathrm{d}$.

\subsubsection{Mobile DOAS measurements at Mount Martin and Mount Mageik}

Airborne mobile DOAS measurements were collected at Mount Martin and Mount Mageik on 15 July 2013. As can be seen in Fig. 3, $\mathrm{SO}_{2}$ was clearly detected east of Mount Martin with maximum $\mathrm{SO}_{2}$ column densities of $\sim 150 \mathrm{ppmm}$. Airborne wind circle measurements (Doukas, 2002 ) were used to calculate a plume speed of $\sim 6 \mathrm{~m} / \mathrm{s}$, and to determine the dominant wind direction from the southwest. Using the measured plume speed, $\mathrm{SO}_{2}$ fluxes of 77, 66 and $81 \mathrm{t} / \mathrm{d}$ were calculated for the three orbits around Mount Martin, with an average value of $75 \mathrm{t} / \mathrm{d}$. These results exhibit good agreement with the scanning DOAS measurements (average of $71 \mathrm{t} / \mathrm{d}$ ), even though the plume scans were incomplete and possible variations in wind speed were not considered. Notable quantities of $\mathrm{SO}_{2}$ were also detected close to the ground near the base camp (Baked Mountain, Figs. 1, 3a) where measurements commenced, as well as NW of Mount Mageik (Fig. 3a). In fact, nearly the entire region showed slightly above background $\mathrm{SO}_{2}$ emissions, with the exception of south of Mount Martin and Mount Mageik, where the lowest $\mathrm{SO}_{2}$ column densities were observed (Fig. 3a). Given that the strong emission from Mount Martin were observed E-NE of the Martin crater, and that no $\mathrm{SO}_{2}$ was detected $\mathrm{E}$ of Mageik, we conclude that only Mount Martin emits detectable quantities of $\mathrm{SO}_{2}$ (Fig. 3b). Thus, the $\mathrm{SO}_{2}$ seen at Baked Mountain as well as NW of Mount Mageik is interpreted to be emanating from Mount Martin volcano. This interpretation is consistent with the dominant wind direction on 15 July, the close proximity of the two volcanoes ( $7 \mathrm{~km}$ apart), as well as the below detection limit quantities of $\mathrm{SO}_{2}$ measured in both fumarole samples and the MultiGAS instrument from Mount Mageik throughout the study period (Fig. 3). 
Table 2

Major species fumarole composition (in mol\%) from Trident and Mount Mageil

\begin{tabular}{|c|c|c|c|c|c|c|c|c|c|c|c|c|c|c|c|c|c|c|}
\hline & \multirow[b]{2}{*}{ Temp $\left({ }^{\circ} \mathrm{C}\right)$} & \multicolumn{13}{|l|}{ Mol\% } & \multicolumn{4}{|c|}{$\mathrm{mmol} / \mathrm{mol}$} \\
\hline & & $\mathrm{H}_{2} \mathrm{O}$ & $\mathrm{CO}_{2}$ & $\mathrm{H}_{2} \mathrm{~S}$ & $\mathrm{HCl}$ & $\mathrm{HF}$ & $\mathrm{NH}_{3}$ & $\mathrm{~N}_{2}$ & $\mathrm{O}_{2}$ & $\mathrm{Ar}$ & $\mathrm{H}_{2}$ & $\mathrm{CH}_{4}$ & $\mathrm{CO}$ & $\mathrm{He}$ & Ethane & Ethene & Propane & Propene \\
\hline TRI1 & 94 & 92.3 & 6.08 & 0.49 & $1.2 \mathrm{E}-04$ & $1.0 \mathrm{E}-04$ & $1.6 \mathrm{E}-04$ & 0.072 & $6.4 \mathrm{E}-04$ & $1.3 \mathrm{E}-04$ & 0.86 & 0.19 & 0.0038 & $2.5 \mathrm{E}-05$ & 0.015 & 0.00012 & 0.00289 & 0.0010 \\
\hline TRI2 & 94 & 92.2 & 6.09 & 0.55 & $1.4 \mathrm{E}-04$ & $9.4 \mathrm{E}-05$ & $1.8 \mathrm{E}-04$ & 0.061 & $6.7 \mathrm{E}-04$ & $1.4 \mathrm{E}-04$ & 0.97 & 0.13 & 0.0040 & $1.7 \mathrm{E}-05$ & 0.023 & 0.00014 & 0.00478 & 0.0013 \\
\hline MGK1 & 92 & 96.6 & 3.09 & 0.12 & $1.7 \mathrm{E}-05$ & 0 & $5.0 \mathrm{E}-06$ & 0.13 & 0.0061 & $1.1 \mathrm{E}-03$ & 0.013 & $7.2 \mathrm{E}-04$ & $3.4 \mathrm{E}-06$ & $3.3 \mathrm{E}-05$ & 0.0078 & 0 & 0.0040 & 0.000035 \\
\hline MGK2 & 93 & 96.8 & 2.99 & 0.12 & $1.9 \mathrm{E}-05$ & 0 & $5.5 \mathrm{E}-06$ & 0.088 & $3.9 \mathrm{E}-04$ & $7.2 \mathrm{E}-04$ & 0.016 & $9.7 \mathrm{E}-04$ & $8.3 E-06$ & $2.8 \mathrm{E}-05$ & 0.015 & 0 & 0.0076 & 0.000080 \\
\hline
\end{tabular}

Table 3

Isotopic composition of measured Trident and Mount Mageik fumarole samples and steam condensate.

\begin{tabular}{|c|c|c|c|c|c|c|c|c|c|c|c|c|c|c|c|c|c|}
\hline & $\mathrm{R} / \mathrm{R}_{\mathrm{A}}{ }^{\mathrm{a}}$ & ${ }^{4} \mathrm{He} /{ }^{20} \mathrm{Ne}$ & $\mathrm{R}_{\mathrm{C}} / \mathrm{R}_{\mathrm{A}}$ & $\delta^{15} \mathrm{~N}^{\mathrm{b}}$ & $\delta \mathrm{D}-\mathrm{H}_{2} \mathrm{O}^{\mathrm{c}}$ & $\delta^{18} \mathrm{O}-\mathrm{H}_{2} \mathrm{O}^{\mathrm{c}}$ & $\delta^{13} \mathrm{C}^{-\mathrm{CO}_{2}{ }^{\mathrm{d}}}$ & $\delta^{13} \mathrm{C}_{-} \mathrm{CH}_{4}$ & $\delta^{13} \mathrm{C}-\mathrm{C}_{2} \mathrm{H}_{6}$ & ${ }^{13} \mathrm{C}-\mathrm{C}_{3} \mathrm{H}_{8}$ & $\delta^{13} \mathrm{C}-\mathrm{C}_{4} \mathrm{H}_{10}$ & ${ }^{13} \mathrm{C} /{ }^{12} \mathrm{C}$ & $\delta^{34} \mathrm{~S}-\mathrm{H}_{2} \mathrm{~S}^{\mathrm{e}}$ & ${ }^{40} \mathrm{Ar} /{ }^{36} \mathrm{Ar}^{\mathrm{f}}$ & ${ }^{3} \mathrm{He}(\mathrm{mmol} / \mathrm{mol})$ & $\mathrm{CO}_{2} / 3 \mathrm{He}$ & $\mathrm{N}_{2} /{ }^{\beta} \mathrm{He}$ \\
\hline TRI1 & 7.01 & 8.86 & 7.24 & 3.53 & -71.31 & -2.75 & -11.11 & -20.5 & -24.4 & -22.9 & $(-23.9)$ & 0.01111 & 2.4 & 312 & $3.3 \mathrm{E}-08$ & $2.4 \mathrm{E}+10$ & $2.83 \mathrm{E}+08$ \\
\hline TRI2 & 7.07 & 9.62 & 7.28 & 3.2 & -76.40 & -3.76 & -10.94 & -20.8 & -23.9 & -22.3 & NA & 0.01111 & 2.2 & 302 & $2.2 \mathrm{E}-08$ & $3.6 \mathrm{E}+10$ & $3.60 \mathrm{E}+08$ \\
\hline MGK1 & 7.4 & 13.52 & 7.56 & 0.59 & -85.39 & -4.99 & -8.61 & -31.1 & -27.7 & -26.5 & -25.9 & 0.01114 & -1.5 & 296 & $1.0 \mathrm{E}-07$ & $8.8 \mathrm{E}+09$ & $3.60 \mathrm{E}+08$ \\
\hline MGK2 & NA & 0.37 & NA & -0.02 & -90.13 & -5.73 & -8.94 & -30.6 & -28 & -27 & -26.7 & 0.01114 & -1.8 & 297 & NA & NA & NA \\
\hline Rainwater & NA & NA & NA & NA & -115.06 & -15.15 & NA & NA & NA & NA & NA & NA & NA & NA & NA & NA & NA \\
\hline
\end{tabular}

${ }^{\text {a }}$ The ${ }^{3} \mathrm{He} /{ }^{4} \mathrm{He}$ reference standard for air $\left(\mathrm{R}_{\mathrm{A}}\right)$ has a value of $1.39 \times 10^{-6}$ (Fischer et al. 2002).

${ }^{\text {b }}$ The ${ }^{15} \mathrm{~N} /{ }^{14} \mathrm{~N}$ reference standard from air has a value of $3676 \times 10^{-6}$ (Junk and Svec, 1958).

${ }^{c}$ The ${ }^{2} \mathrm{H} /{ }^{1} \mathrm{H}$ and ${ }^{18} \mathrm{O} /{ }^{16} \mathrm{O}$ on water reference standards based on Vienna Standard Mean Oceanic Water have values of $155.76 \times 10^{-6}$ (Hagemann et al., 1970) and $2005.20 \times 10^{-6}($ Baertschi, 1976$)$, respectively.

${ }^{d}$ The ${ }^{13} \mathrm{C} /{ }^{13} \mathrm{C}$ reference standard is known as Pee Dee Belemnite (PDB) and has a value of $11,237.2 \times 10^{-6}$ (Craig, 1957).

e The ${ }^{34} \mathrm{~S}{ }^{32} \mathrm{~S}$ reference standard is known as Vienna Canon Diablo Triolite (VCDT) has a value of 45,004.5 $\times 10^{-6}$ (Jensen and Nakai, 1962).

${ }^{\mathrm{f}} \mathrm{The}{ }^{40} \mathrm{Ar} /{ }^{36} \mathrm{Ar}$ reference standard for air is 295.5 (Marty et al., 1995). 

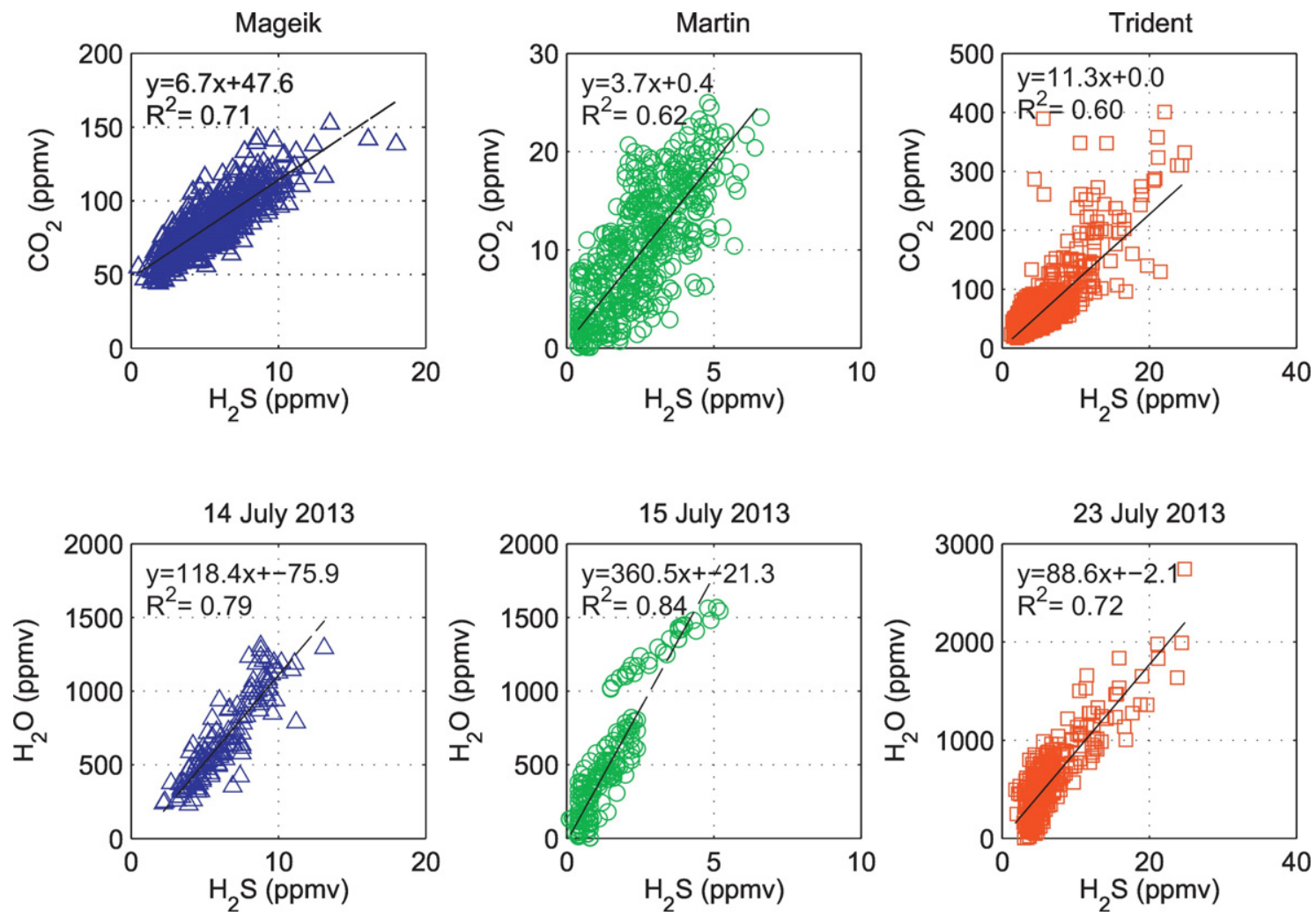

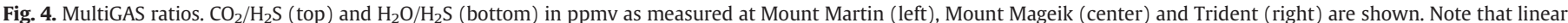

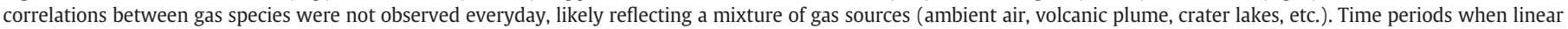
correlations are observed are shown here.

\subsubsection{Total volatile flux estimates for Mount Martin}

Fortuitously, one of the only days in which linear correlations of $\mathrm{SO}_{2} /$ $\mathrm{H}_{2} \mathrm{~S}, \mathrm{CO}_{2} / \mathrm{H}_{2} \mathrm{~S}$ and $\mathrm{H}_{2} \mathrm{O} / \mathrm{H}_{2} \mathrm{~S}$ were observed in the Mount Martin MultiGAS data corresponded with the single day in which airborne and scanning DOAS measurements enabled $\mathrm{SO}_{2}$ flux calculation from Mount Martin to be made. These combined datasets acquired on 15 July 2013 allowed total volatile fluxes to be estimated, using the measured molar ratios, the molar masses of each species and the calculated average $\mathrm{SO}_{2}$ flux from the airborne mobile-DOAS measurements (see values in Table 5). Assuming that these four species make up the majority of the emitted volatiles (Gerlach, 2004), we calculate a total flux of gases released from Mount Martin of $\sim 26,580 \mathrm{t} / \mathrm{d}$ (Table 5). This total volatile flux includes $\sim 75 \mathrm{t} / \mathrm{d} \mathrm{SO}_{2}, 133 \mathrm{t} / \mathrm{d} \mathrm{H}_{2} \mathrm{~S}, 638 \mathrm{t} / \mathrm{d} \mathrm{CO}_{2}$ and $25,734 \mathrm{t} / \mathrm{d} \mathrm{H}_{2} \mathrm{O}$. We note that $\sim 96.8 \%$ of this total volatile flux is $\mathrm{H}_{2} \mathrm{O}$. We speculate that a significant portion of the water, comprising the majority of this total volatile flux, is meteoric in origin; however without chemical and/or isotopic constraints we cannot determine the quantity of meteoric water involved. Further complicating interpretations, we expect that this total water flux may be underestimated with respect to the fumarole composition due to condensation of steam prior to measurement by the MultiGAS instrument. This interpretation is consistent with our observations from Mount Mageik and Trident, and suggests that the MultiGAS water concentration may be underestimated by up to a factor of 2 (see details in Section 5.1.1).

Table 4

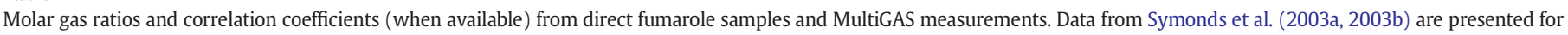
comparison.

\begin{tabular}{|c|c|c|c|c|c|c|c|c|c|c|c|}
\hline & Measurement & Date & Reference & $\mathrm{H}_{2} \mathrm{O} / \mathrm{H}_{2} \mathrm{~S}$ & $\mathrm{R}^{2}$ & $\mathrm{CO}_{2} / \mathrm{H}_{2} \mathrm{~S}$ & $\mathrm{R}^{2}$ & $\mathrm{SO}_{2} / \mathrm{H}_{2} \mathrm{~S}$ & $\mathrm{R}^{2}$ & $\mathrm{H}_{2} \mathrm{O} / \mathrm{CO}_{2}$ & $\mathrm{R}^{2}$ \\
\hline TRI1 & Fumarole & 2013 & This study & 187 & - & 12 & - & nd & - & 15 & - \\
\hline TRI2 & Fumarole & 2013 & This study & 166 & - & 11 & - & nd & - & 15 & - \\
\hline TRI MG & MultiGAS & 2013 & This study & 88.6 & 0.7 & $10.3-11.3$ & 0.6 & nd & - & $8^{*}$ & - \\
\hline Trident & Fumarole & 1994 & Symonds et al., 2003a & - & - & 24.1 & - & - & - & - & - \\
\hline Trident & Fumarole & 1995 & Symonds et al., 2003a & - & - & 15.3 & - & - & - & - & - \\
\hline Trident & Fumarole & 1997 & Symonds et al., 2003a, 2003b & 257 & - & 23.9 & - & - & - & 11 & - \\
\hline Trident & Fumarole & 1998 & Symonds et al., 2003a & - & - & 20.7 & - & - & - & - & - \\
\hline MGK1 & Fumarole & 2013 & This study & 821 & - & 26 & - & nd & - & 31 & - \\
\hline MGK2 & Fumarole & 2013 & This study & 793 & - & 24 & - & nd & - & 32 & - \\
\hline MGK MG & MultiGAS & 2013 & This study & $114-118$ & $0.5-0.9$ & $6-9.5$ & 0.95 & nd & - & $16-19^{*}$ & - \\
\hline Mageik & Fumarole & 1995 & Symonds et al., 2003a & - & - & 10.5 & - & - & - & - & - \\
\hline Mageik & Fumarole & 1997 & Symonds et al., 2003a, 2003b & 262 & - & 10.0 & - & - & - & 26 & - \\
\hline Mageik & Fumarole & 1998 & Symonds et al., 2003a & - & - & 10.1 & - & - & - & - & - \\
\hline Mageik & Fumarole & 1998 & Symonds et al., 2003a & & - & 9.6 & - & - & - & - & - \\
\hline MRTN MG & MultiGAS & 2013 & This study & $351-366$ & $0.7-0.8$ & $1.7-3.7$ & 0.6 & $0.2-0.6$ & 0.90 & $97^{*}$ & - \\
\hline
\end{tabular}

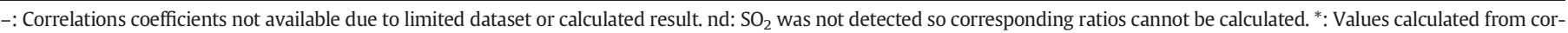
related $\mathrm{H}_{2} \mathrm{O} / \mathrm{H}_{2} \mathrm{~S}$ and $\mathrm{CO}_{2} / \mathrm{H}_{2} \mathrm{~S}$ measurements. 
Table 5

Mount Martin measured major species molar gas ratios and $\mathrm{SO}_{2}$ flux, as well as calculated fluxes for $\mathrm{H}_{2} \mathrm{~S}, \mathrm{CO}_{2}$, and $\mathrm{H}_{2} \mathrm{O}$, and total volatile flux.

\begin{tabular}{lllll}
\hline Gas species & $\begin{array}{l}\text { Molar mass } \\
(\mathrm{g} / \mathrm{mol})\end{array}$ & $\begin{array}{l}\text { Gas } \\
\text { ratios }\end{array}$ & $\begin{array}{l}\text { Measured } \\
\text { molar ratios }\end{array}$ & $\begin{array}{l}\text { Flux } \\
(\mathrm{t} / \mathrm{d})\end{array}$ \\
\hline $\mathrm{SO}_{2}$ & 64 & & & 75 \\
$\mathrm{H}_{2} \mathrm{~S}$ & 34 & $\mathrm{H}_{2} \mathrm{~S}_{\mathrm{SO}_{2}}$ & 3.3 & 133 \\
$\mathrm{CO}_{2}$ & 44 & $\mathrm{CO}_{2} / \mathrm{SO}_{2}$ & 12.4 & 638 \\
$\mathrm{H}_{2} \mathrm{O}$ & 18 & $\mathrm{H}_{2} \mathrm{O} / \mathrm{SO}_{2}$ & 1220 & 25,734 \\
$\begin{array}{l}\text { Total volatile (magmatic }+ \\
\quad \text { meteoric) flux }\end{array}$ & & & 26,580 \\
\end{tabular}

\section{Discussion}

\subsection{Geochemical constraints on subvolcanic conditions}

\subsubsection{Interpretations from volcanic gas chemical composition}

5.1.1.1. Mount Martin. When compared with other arc volcanoes, Mount Martin's gas composition seems to be consistent with both magma degassing and an active hydrothermal system, a system commonly referred to as mixed magmatic-hydrothermal. In addition to moderate fluxes of $\mathrm{CO}_{2}$ and $\mathrm{H}_{2} \mathrm{~S}$ (hydrothermal and magmatic gases), Mount Martin also emits significant quantities of $\mathrm{SO}_{2}(\sim 75 \mathrm{t} / \mathrm{d})$, an unambiguous magmatic gas (Symonds et al., 2001). This $\mathrm{SO}_{2}$ flux is in the range of airborne $\mathrm{SO}_{2}$ flux measurements made at Mount Martin by Doukas and McGee (2007) in 1998, 2004 and 2006, who detected $\mathrm{SO}_{2}$ fluxes ranging from 24 to $114 \mathrm{t} / \mathrm{d}$. The relatively low $\mathrm{SO}_{2} / \mathrm{H}_{2} \mathrm{~S}$ ratio $(\sim 0.3)$ measured via MultiGAS (Table 4) and the presence of a crater lake indicate that Mount Martin also has an active hydrothermal system. This is illustrated in the $\mathrm{CO}_{2}-\mathrm{H}_{2} \mathrm{O}-\mathrm{S}_{\mathrm{t}}$ ternary diagram (where $\mathrm{S}_{\mathrm{t}}=\mathrm{SO}_{2}+\mathrm{H}_{2} \mathrm{~S}$; Fig. 5b), where Mount Martin's median normalized gas composition plots near the overlapping region of magmatic and hydrothermal gases. The low $\mathrm{SO}_{2} / \mathrm{H}_{2} \mathrm{~S}$ observed at Mount Martin can result from several processes in a mixed magmatic-hydrothermal system. Scrubbing, which consists of chemical and physical processes that cause the partial or total removal of acid gases released from a magma source during their uprising toward the surface (Symonds et al., 2001), is common in hydrothermal reservoirs. Therefore the preferential removal of $\mathrm{SO}_{2}$ relative to $\mathrm{CO}_{2}$ and $\mathrm{H}_{2} \mathrm{~S}$ by a hydrothermal reservoir could partially explain the low $\mathrm{SO}_{2} / \mathrm{H}_{2} \mathrm{~S}$ observed at Mount Martin. Additionally, in mixed magmatichydrothermal systems redox conditions can be controlled by either the "sulfur gas buffer" under high temperature, quickly equilibrating magmatic conditions, through the following reaction (Giggenbach, 1987):

$\mathrm{H}_{2} \mathrm{~S}+2 \mathrm{H}_{2} \mathrm{O}=\mathrm{SO}_{2}+3 \mathrm{H}_{2}$

and/or the "rock buffer" under lower temperature, slowly equilibrating systems typical of hydrothermal environments (Giggenbach, 1987), both of which can influence the sulfur speciation. It is notable that significant quantities of $\mathrm{SO}_{2}$ were released from Mount Martin in comparison with Mount Mageik and Trident volcano, even in the presumed presence of a hydrothermal system, which suggests a significant contribution of high-temperature magmatic gases to Mount Martin's total gas emissions.

5.1.1.2. Mount Mageik. The chemical composition of Mount Mageik's gases is composed of relatively high proportions of $\mathrm{CO}_{2}$ and $\mathrm{H}_{2} \mathrm{~S}$, typical of hydrothermal gases, in addition to low and/or below detection limit quantities of the acid magmatic gases $\mathrm{HCl}$ and $\mathrm{SO}_{2}$. The absence of acid magmatic gases, is further supported by below detection limit fluxes of $\mathrm{SO}_{2}$, and argues for a hydrothermal-dominated system. This interpretation is illustrated in the $\mathrm{CO}_{2}-\mathrm{S}_{\mathrm{t}}-\mathrm{HCl}$ and $\mathrm{CO}_{2}-\mathrm{H}_{2} \mathrm{O}-\mathrm{H}_{2} \mathrm{~S}$ ternary diagrams (Fig. 5) where the Mount Mageik normalized gas compositions plot well within the typical compositional regions associated with hydrothermal gases. The relatively low $\mathrm{N}_{2} / \mathrm{Ar}$ ratios $(<125)$ observed in Mount Mageik's fumarolic emissions are lower than the typical ratios from subduction zone volcanoes (Giggenbach, 1992b), and suggest mixing between the sampled gases and ambient air and/or air-saturated waters (Fischer et al., 1998). This is further supported by low $\mathrm{He} / \mathrm{Ne}$ ratios with respect to typical magmatic gases (Fig. 7b).

During the 2013 field campaign the sampled fumaroles and deployed MultiGAS instruments had different locations that likely contributed to differences in measured gas composition. The Mount Mageik MultiGAS instrument was deployed on the crater rim, $~ 360 \mathrm{~m}$ from the sampled fumaroles and measured the composition of the volcanic
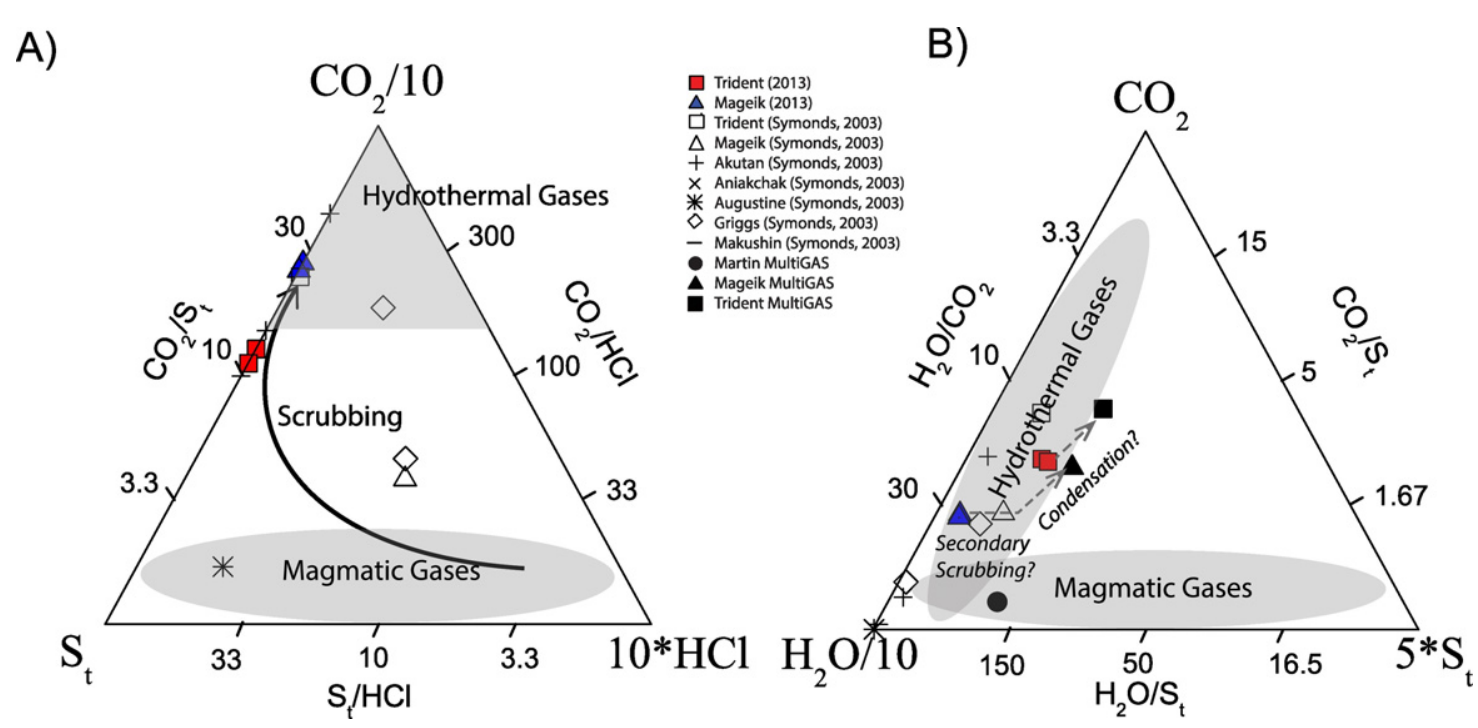

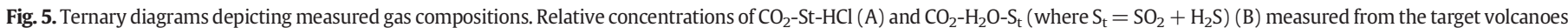

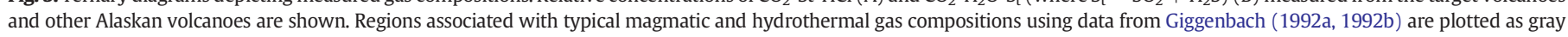

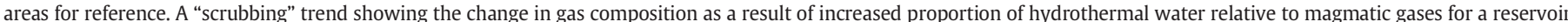

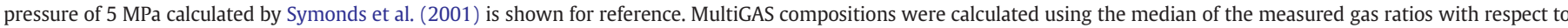

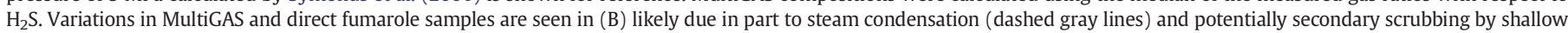
meteoric water at Mount Mageik. See text for discussion. 
plume, representing numerous coalesced fumaroles as well as direct degassing off the crater lake (e.g. Werner et al., 2006; Shinohara et al., 2015; Tamburello et al., 2015; Gunawan et al., 2016; de Moor et al., 2016). The two Mount Mageik fumarole samples were collected from the edge of the fumarole field to minimize healthy and safety risk, and may not be representative of the entire fumarole field. The $\mathrm{H}_{2} \mathrm{O} / \mathrm{H}_{2} \mathrm{~S}$ and $\mathrm{H}_{2} \mathrm{O} / \mathrm{CO}_{2}$ measured in the fumarole samples are factors of $\sim 8$ and $\sim 2$ times greater than measured by the MultiGAS instrument, respectively (Fig. 5; Table 4). Additionally, the $\mathrm{CO}_{2} / \mathrm{H}_{2} \mathrm{~S}$ molar ratios measured in the fumarole samples of $\sim 24-26$ are $\sim 2.5-4$ times larger than measured by the Mount Mageik MultiGAS instrument (6-9.5) (Table 4). Higher relative concentrations of $\mathrm{H}_{2} \mathrm{O}$ with respect to $\mathrm{CO}_{2}$ and $\mathrm{H}_{2} \mathrm{~S}$ observed in the fumaroles compared with the MultiGAS measurements are also observed at Trident Volcano (see below) and can be explained in part by condensation of the plume as it disperses and cools within the atmosphere. Due to the observations of: (1) inconsistently higher $\mathrm{H}_{2} \mathrm{O} / \mathrm{H}_{2} \mathrm{~S}(\sim 8 \times)$ and $\mathrm{H}_{2} \mathrm{O} / \mathrm{CO}_{2}(\sim 2 \times)$ ratios observed in the fumarole samples in comparison with the MultiGAS measurements, and (2) significantly higher $\mathrm{CO}_{2} / \mathrm{H}_{2} \mathrm{~S}$ and $\mathrm{H}_{2} \mathrm{O} / \mathrm{H}_{2} \mathrm{~S}$ ratios in the fumarole samples compared with the MultiGAS measurements, we conclude that an additional source or process must be influencing the gas geochemistry within Mount Mageik's system. The higher proportion of $\mathrm{CO}_{2} / \mathrm{H}_{2} \mathrm{~S}$ in the fumarole samples suggests a higher degree of gas scrubbing by meteoric water (Symonds et al., 2003b; Di Napoli et al., 2016). The simplest explanation of this observation is that the peripheral fumaroles sampled in this study have a larger meteoric water influence than the bulk plume composition measured by MultiGAS (Fig. 2). In this scenario, secondary scrubbing by shallow meteoric water is preferentially removing $\mathrm{H}_{2} \mathrm{~S}$ from the gas phase (Fig. 5b).

5.1.1.3. Trident Volcano. Like Mount Mageik, the chemical composition of Trident's volcanic gases is dominated by the hydrothermal gases $\mathrm{H}_{2} \mathrm{O}$, $\mathrm{CO}_{2}$ and $\mathrm{H}_{2} \mathrm{~S}$ with minimal quantities of acid magmatic gases. Also, like Mount Mageik, Trident's normalized gas composition plots near and within the typical regions associated with hydrothermal gases shown in the ternary diagrams of Fig. 5. Unlike Mount Mageik, Trident's gases also contain high concentrations of reduced gases (e.g. $\mathrm{CO}, \mathrm{CH}_{4}, \mathrm{H}_{2}$ and light hydrocarbons), in comparison with typical volcanic-hydrothermal systems, which may reflect a strongly reducing C-rich environment. As previously proposed by Symonds et al. (2003a, 2003b), we speculate that this unusual composition may be explained by thermal decomposition of crustal sediments overlying the hydrothermal system (see Section 5.2 for details). In contrast to Mount Mageik, the $\mathrm{N}_{2} / \mathrm{Ar}$ ratios of Trident's emissions range from 445-557, indicating minimal air contamination of the samples.

At Trident Volcano only 90 m separated the MultiGAS instrument from the sampled fumaroles. Good agreement in molar $\mathrm{CO}_{2} / \mathrm{H}_{2} \mathrm{~S}$ ratios is observed between the fumarole samples $(11-12)$ and MultiGAS plume measurements (10.3-11.3), which suggests fairly homogenous degassing within the Trident fumarole field (Table 4). The $\mathrm{H}_{2} \mathrm{O} / \mathrm{CO}_{2}$ and $\mathrm{H}_{2} \mathrm{O} / \mathrm{H}_{2} \mathrm{~S}$ ratios observed in the Trident fumaroles are $\sim 2$ times higher than observed in the MultiGAS measurements (Table 4). The consistent two-fold larger proportion of fumarolic $\mathrm{H}_{2} \mathrm{O}$ with respect to $\mathrm{CO}_{2}$ and $\mathrm{H}_{2} \mathrm{~S}$, suggests that a single process can explain the larger quantities of $\mathrm{H}_{2} \mathrm{O}$ relative to the MultiGAS measurements. We propose that condensation of water in the atmosphere is the most likely process to preferentially remove water from the plume prior to sampling by the MultiGAS instrument (Fig. 5b).

\subsubsection{Geothermometry constraints on hydrothermal reservoir conditions}

Since the chemical composition of volatiles released from the target volcanoes are consistent with subsurface hydrothermal systems, we employ gas geothermometry techniques here in an effort to constrain temperature, pressure and redox conditions of the hydrothermal reservoirs. Hydrothermal reservoir temperature can be reliably estimated by considering the chemical equilibria among the measured gas species: $\mathrm{H}_{2} \mathrm{O}, \mathrm{CO}_{2}, \mathrm{H}_{2}, \mathrm{CO}$ and $\mathrm{CH}_{4}$ (Chiodini and Marini, 1998), as described by following chemical reactions:

$\mathrm{CO}_{2}+\mathrm{H}_{2} \Leftrightarrow \mathrm{CO}+\mathrm{H}_{2} \mathrm{O}$

$3 \mathrm{CO}_{2}+\mathrm{CH}_{4} \Leftrightarrow 4 \mathrm{CO}+2 \mathrm{H}_{2} \mathrm{O}$

whose temperature dependence is given by:

$\log \left(\mathrm{X}_{\mathrm{CO}} / \mathrm{X}_{\mathrm{CO} 2}\right)-\log \left(\mathrm{X}_{\mathrm{H} 2} / \mathrm{X}_{\mathrm{H} 2 \mathrm{O}}\right)=-2248 / \mathrm{T}+2.485$

$3 \log \left(\mathrm{X}_{\mathrm{CO}} / \mathrm{X}_{\mathrm{CO} 2}\right)+\log \left(\mathrm{X}_{\mathrm{CO}} / \mathrm{X}_{\mathrm{CH} 4}\right)=-17,813 / \mathrm{T}+19.605$

The dependence of $\left[\log \left(\mathrm{H}_{2} \mathrm{O} / \mathrm{H}_{2}\right)+\log \left(\mathrm{CO} / \mathrm{CO}_{2}\right)\right]$ and $[3 \log (\mathrm{CO} /$ $\left.\left.\mathrm{CO}_{2}\right)+\log \left(\mathrm{CO} / \mathrm{CH}_{4}\right)\right]$, in: (i) a single saturated vapor phase (vapor), (ii) a single saturated liquid phase (liquid) and (iii) vapors produced by single-step vapor separation (SSVS), on temperature $\left(T_{s}\right)$, is graphically described in Fig. 7a. The main advantage of this approach is that the two sums of log-ratios depend only on temperature and water fugacity, and are not controlled by redox conditions provided that all gas constituents occur in overall equilibrium. According to the model results presented in Fig. 7a, the Mount Mageik fumarolic gases have attained equilibrium in a vapor phase at $220-260{ }^{\circ} \mathrm{C}$. In contrast, the Trident samples plot out of the vapor-liquid grid, in the field of superheated vapors at equilibrium temperatures $\sim 380^{\circ} \mathrm{C}$ (Chiodini and Marini, 1998). Considering the relatively low outlet temperature of the Trident fumaroles, which were close to the boiling point of water, we expect that steam condensation occurred, which can shift these gas compositions off the vapor equilibrium line. Similar equilibrium temperatures are obtained by separately considering the chemical equilibrium of the $\mathrm{H}_{2}$ / $\mathrm{H}_{2} \mathrm{O}$ and $\mathrm{CO} / \mathrm{CO}_{2}$ redox pairs (Fig. $7 \mathrm{~b}$ ) that rapidly respond to changes in chemical-physical conditions (Giggenbach, 1987), such as during the uprising of the hydrothermal fluids to the surface. The Mount Mageik gases plot close to the line of vapors equilibrated under the control of the D'Amore and Panichi (1980) buffer system ("A\&P" in Fig. 7b). On the contrary, the $\log \left(\mathrm{X}_{\mathrm{H} 2} / \mathrm{X}_{\mathrm{H} 2 \mathrm{O}}\right)$ ratios $\left(\mathrm{R}_{\mathrm{H}}\right)$ of the Trident gases $(\sim$ -2 ) are significantly higher (i.e. more reducing) than that established under the control of the $\mathrm{FeO}-\mathrm{FeO}_{1.5}$ redox pair $(-2.8)$, which is the previously mentioned "rock" redox buffer, typically assumed for hydrothermal fluids (Giggenbach, 1987). Such high $R_{H}$ values have only been found in high-temperature $\left(>800^{\circ} \mathrm{C}\right)$ gases from active volcanoes, where redox conditions are controlled by the $\mathrm{H}_{2} \mathrm{~S} / \mathrm{SO}_{2}$ redox pair, or in fluids in contact with ultramafic rocks affected by serpentinization (Taran et al., 2002, 2010), neither scenario seems likely here. The fayalite-magmetite-quartz (FMQ) buffer system can also produce $R_{H}>$ -2.8 , although this mineral assemblage is thought to be uncommon in a hydrothermal environment (Giggenbach, 1987), though such conditions have been observed under low-grade metamorphism of sedimentary rocks (Holloway, 1984). Steam separation due to condensation, a process already invoked to justify the left-shift of the Trident gases in Fig. 7, may have produced an increase of the $\log \left(\mathrm{X}_{\mathrm{H} 2} /\right.$ $\mathrm{X}_{\mathrm{H} 2 \mathrm{O}}$ ) ratios; however, it cannot explain the highly reducing conditions that control the chemical equilibria among the carbon-bearing redox species (Fig. 7c). Considering the predominantly sedimentary basement and that patches of coal-bearing rocks of Cenozoic age inter-bedded with volcanic rocks commonly occur within the Katmai region (Keller and Reiser, 1959), along with the occurrence of dark gray consolidated material, presumed to be organic in nature, composing the ground near the fumarole field, we speculate that C-rich soils and rock beneath Trident's fumarole field may be influencing fumarole gas composition. Hence, in this geological framework, $\mathrm{CO}_{2}$ and $\mathrm{C}$ (graphite) may be able to fix the redox conditions. This is consistent with results by Holloway (1984) who finds that at temperatures $<400{ }^{\circ} \mathrm{C}$ and pressures between 300-1000 bars, $\mathrm{CO}_{2}$ and/or $\mathrm{CH}_{4}$-rich fluids can coexist in equilibrium with graphite at redox conditions similar to the FMQ buffer. In this 
case, the chemical reactions among $\mathrm{CO}_{2}, \mathrm{H}_{2}$, and $\mathrm{CO}$ can be written as follows:

$\mathrm{CO}_{2}+2 \mathrm{H}_{2} \Leftrightarrow 2 \mathrm{H}_{2} \mathrm{O}+\mathrm{C}$

$\mathrm{CO}_{2}+\mathrm{C} \Leftrightarrow 2 \mathrm{CO}$

On the basis of the equilibrium constant of reaction (6) $\left(\mathrm{K}_{6}\right), p \mathrm{CO}_{2}$ can be calculated, as follows:

$\log \left(p \mathrm{CO}_{2}\right)=2 \log \left(p \mathrm{H}_{2} \mathrm{O} / p \mathrm{H}_{2}\right)-\log \mathrm{K}_{6}$

whereas the dependence of $\mathrm{K}_{6}$ on temperature in the gas phase is given by:

$\log \mathrm{K}_{6}=-5.26+4482 / \mathrm{T}(\mathrm{K})$

Considering that the Trident fumaroles had $2 \log \left(\mathrm{pH}_{2} \mathrm{O} / \mathrm{pH}_{2}\right)=4$ (Table 2), at the equilibrium temperature calculated in the $\mathrm{H}_{2} \mathrm{O}-\mathrm{CO}_{2}$ $\mathrm{H}_{2}-\mathrm{CO}-\mathrm{CH}_{4}$ system $\left(\sim 380^{\circ} \mathrm{C}\right)$ the value of $p \mathrm{CO}_{2}$ is $\sim 60$ bar. Hence, according to the $\mathrm{CO}_{2}$ concentration $(0.06 \%$; Table 2$)$, the $p$ tot value at this volcano is $\sim 1$ kbar.

On the other hand, the $\mathrm{pCO}_{2}$ value can be calculated on the basis of the equilibrium constant of reaction (7) $\left(\mathrm{K}_{7}\right)$, as follows:

$\log \left(p \mathrm{CO}_{2}\right)=\log (p \mathrm{CO})^{2}-\log \mathrm{K}_{7}$

The dependence of $\mathrm{K}_{7}$ on temperature is given by:

$\log \mathrm{K}_{7}=9.34-9063 / \mathrm{T}(\mathrm{K})$

Thus, we obtain the $p \mathrm{CO}_{2}$ value based on reaction (7) of $\sim 66$ bar, which is consistent with that computed using reaction (6).

If we assume a crustal density of $2550 \mathrm{~kg} / \mathrm{m}^{3}$ (Kienle, 1970), we estimate that the hydrothermal reservoir below Trident resides at $\sim 4 \mathrm{~km}$ depth (below the surface, or $\sim 3 \mathrm{~km}$ b.s.l). This depth is $\sim 1 \mathrm{~km}$ greater than that estimated by Symonds et al. (2003b) in 1997 calculated using the method of D'Amore and Panichi [1980]. Much of this discrepancy is likely due to our new method being more sensitive to higherpressure conditions and likely suggests relatively stable geothermal conditions at depth; however since $\mathrm{CO}$ concentrations were not reported in Symonds et al. (2003b) a direct comparison between our datasets is not possible.

As far as Mount Mageik is concerned, an estimation of $p \mathrm{CO}_{2}$ can be obtained on the basis of the $\mathrm{CO}$ and $\mathrm{H}_{2}$ concentrations, as suggested by Chiodini and Cioni (1989), as follows:

$\log \left(p \mathrm{CO}_{2}\right)=3.573-46 / \mathrm{T}(\mathrm{K})-\log \left(\mathrm{H}_{2} / \mathrm{CO}\right)$

At $260{ }^{\circ} \mathrm{C}$, i.e. the maximum temperature calculated for Mageik in the $\mathrm{H}_{2} \mathrm{O}-\mathrm{CO}_{2}-\mathrm{H}_{2}-\mathrm{CO}-\mathrm{CH}_{4}$ system (Fig. 7a), the computed $p \mathrm{CO}_{2}$ value is $\sim 1.6$ bar that, considering the $\mathrm{CO}_{2}$ molar fraction ( 0.03; Table 2$)$, indicates that $p$ tot $\sim 53$ bar. This pressure would correspond to an unrealistic shallow depth of the Mageik hydrothermal system $(\sim 0.2 \mathrm{~km})$, if we assume it lies directly above the magmatic system. This apparent shallow depth could be due to re-equilibrium of the kinetically fast $\mathrm{H}_{2}$-CO pair during the fluids uprising and/or to secondary scrubbing CO (whose concentrations are more than two orders of magnitude lower than those measured in the Trident gases) when the hydrothermal fluids approached the surface. We consider this depth to be an upper limit of Mageik's hydrothermal system and note that greater depths are plausible.

\subsection{Geochemical constraints on volatile sources}

The isotopic composition of volcanic gases from Mount Mageik and Trident are consistent with both deep and shallow volatile sources, including subducted fluids, mantle-derived magma, and crust-derived volatiles. The ${ }^{3} \mathrm{He} /{ }^{4} \mathrm{He}$ ratios from both Mount Mageik and Trident reflect degassing of magma generated through partial melting of a Mid Ocean Ridge Basalt-like mantle wedge (MORB $R_{C} / R_{A}=8 \pm 1$ (Graham, 2002)) and indicate minimal interaction with fluids and/or rocks bearing crustal-derived radiogenic ${ }^{4} \mathrm{He}$. The $\mathrm{R}_{\mathrm{C}} / \mathrm{R}_{\mathrm{A}}$ values of $\sim 7.6$ at Mount Mageik and $~ 7.3$ at Trident (Fig. $7 \mathrm{~b}$ and Table 3 ) are within the range of the typical values of gases from most of arc volcanoes (e.g., Poreda and Craig, 1989; Hilton et al., 2002; Taran, 2009; Di Piazza et al., 2015; Robidoux et al., 2017), and indicate the presence of active magma degassing in the subsurface. The isotopes on the sampled steam condensate from Mount Mageik and Trident are relatively enriched in both $\delta \mathrm{D}$ and $\delta^{18} \mathrm{O}$ in comparison with local meteoric water, and may reflect mixing between recycled sea-water referred to as andesitic water (Taran et al., 1989) and meteoric water sources. If we assume that these isotopic compositions are due solely to two-component mixing, we calculate that between $27-32 \%$ of Mount Mageik's steam is andesitic water and $\sim 68-73 \%$ is meteoric in origin, while $41-$ $46 \%$ of Trident's steam is andesitic water and $\sim 54-59 \%$ is meteoric in origin (Table 6, Fig. 7) (Giggenbach, 1992a). However, the very low quantities of $\mathrm{Cl}$ in our steam condensate $(\sim 0.1-0.2 \mathrm{mg} / \mathrm{L}$ from both volcanoes), likely due to scrubbing, prevent confirmation of these values. Acknowledging that these water isotopic values are shifted off the two-component mixing line in the direction of higher $\delta^{18} \mathrm{O}$ (Fig. 6 ), it is likely that other processes (e.g. isotopic fractionation) are influencing their isotopic composition. This $\delta^{18} \mathrm{O}$ shift is commonly seen in volcanic settings and can be attributed to chemical reactions between water and host rock in the subsurface hydrothermal system (Craig, 1963) as well as through steam condensation.

When Mount Mageik and Trident's $\delta^{15} \mathrm{~N}$ values are considered along with $\mathrm{N}_{2}$ /He ratios, mixing between three nitrogen sources: ambient air (likely through interaction with air-saturated meteoric water), sediment, and mantle, is apparent. Applying the three component mixing model of Sano and Marty (1995) and the methods of Fischer et al. (2002), we find that the $\mathrm{N}_{2}$ emissions from Mount Mageik are sourced primarily from atmospheric air ( 84-92\%), with minor contributions from both sediment $(\sim 3-12 \%)$ and mantle ( 4\%). The significant atmospheric component to Mount Mageik's fumarole emissions is further supported by ${ }^{40} \mathrm{Ar} /{ }^{36} \mathrm{Ar}$ ratios that are similar to air (Table 4). In contrast, Trident's nitrogen is sourced primarily from sediment $(\sim 52-$ $58 \%)$, with moderate contributions from air ( 37-44\%), and minor contributions from the mantle ( 3-4\%) (Fig. 6; Table 6$)$.

Next, we consider the $\delta^{13} \mathrm{C}-\mathrm{CO}_{2}$ from Mount Mageik and Trident's volcanic gases along with the $\mathrm{CO}_{2} /{ }^{3} \mathrm{He}$ ratios. Using the traditional three-component mixing model of Sano and Marty (1995) we find the observed compositions to be consistent with mixing between carbonate minerals, presumed to be from the altered oceanic crust, sediment and mantle, and calculate that $~ 63 \%$ of Mageik's carbon is sourced from carbonate minerals, $20 \%$ from sediment, and $~ 17 \%$ from the mantle. Similarly, Trident's carbon is calculated to be sourced from $\sim 64 \%$ carbonate minerals, $30 \%$ sediment, and $\sim 5 \%$ mantle (Fig. 6; Table 6). At most volcanic arc settings, carbonate and sediment sources are presumed to reflect subducted slab provenance (e.g., Sano and Marty, 1995; Snyder et al., 2001); however, due to the crustal sedimentary rocks beneath the Katmai volcanoes (Keller and Reiser, 1959), we cannot conclusively distinguish subducted slab from crustal carbon using these standard techniques. It is notable that when the three-component mixing model results for nitrogen and carbon calculated here are normalized to consider only mantle and sediment (including both organic sediment and carbonate) sources, good agreement is found between the two models. Specifically, we find 4-7\% mantle and 93-96\% sedimentary sources for Trident's nitrogen and carbon, and 17-24\% mantle and 76-83\% sedimentary sources for Mount Mageik's nitrogen and carbon (Table 6 ). This finding suggests that both $\mathrm{CO}_{2}$ and $\mathrm{N}_{2}$ emissions are derived from the same source (i.e. subducted slab and/or crust). Several studies have used arc-wide geochemical trends to distinguish between crustal 


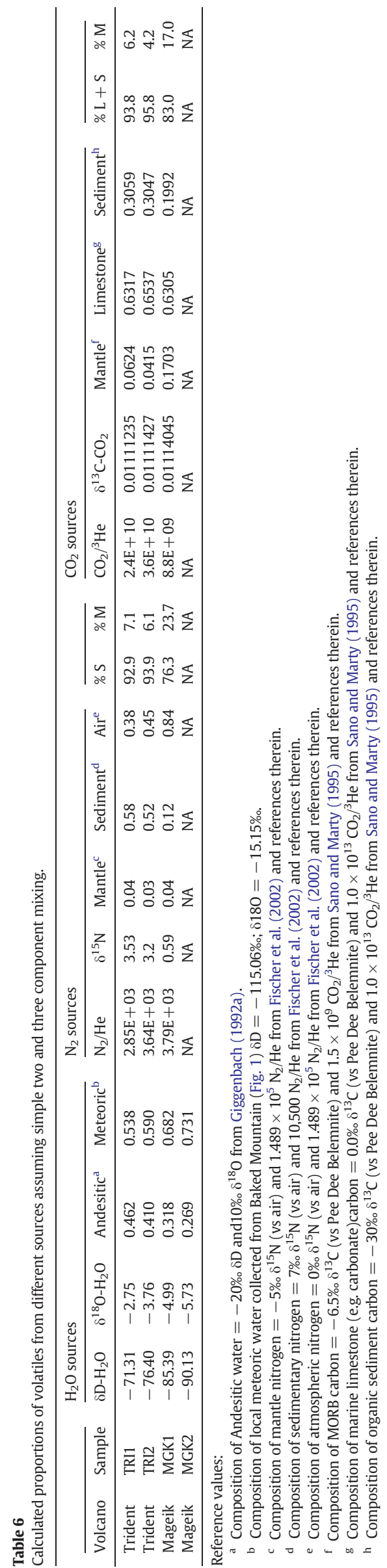

and subducted carbon sources. Specifically, a new study by Aiuppa et al. (2017) used arc-wide trends in $\mathrm{CO}_{2} / \mathrm{S}$ ratios to identify crustal contributions to volcanic emissions. Based on the low $\mathrm{CO}_{2} / \mathrm{S}$ observed from several Aleutian Arc volcanoes they infer minimal crustal C contributions to Aleutian Arc emissions. Conversely, Symonds et al. (2003a), observed linear correlations between $\mathrm{CH}_{4} /{ }^{3} \mathrm{He}, \mathrm{N}_{2} /{ }^{3} \mathrm{He}$ and $\mathrm{CO}_{2} /{ }^{3} \mathrm{He}$ in fumarole samples for several Aleutian and Cascades arc volcanoes and used these correlations to infer a singular crustal $\mathrm{N}_{2}$ and $\mathrm{CO}_{2}$ source. They argue that the linear correlations between these three volatile species, while considering the instability of $\mathrm{CH}_{4}$ at magmatic temperatures, suggests that the three correlating species must all be sourced from crustal sedimentary rocks. This later interpretation is further supported by the analysis of subducted sediment composition by Plank and Langmuir (1998) who find primarily silicate sediments, with no detectable carbon, being subducted beneath mainland Alaska and the Alaskan Peninsula in the two sediment cores analyzed. Without clear consensus we conclude that more work is needed to robustly distinguish between crustal and subducted carbon sources in Aleutian Arc emissions.

We observe $\delta^{34} \mathrm{~S}-\mathrm{H}_{2} \mathrm{~S}$ values from Mount Mageik of $\sim 1.7 \%$ 。-CDT and from Trident Volcano of $\sim+2.3 \%$ 。-CDT. These values are somewhat lower than typically observed from hydrothermal gases (Marini et al., 2011) and/or arc volcanoes (e.g. de Moor et al., 2013). The depleted $\delta^{34} \mathrm{~S}-\mathrm{H}_{2} \mathrm{~S}$ signatures from both volcanoes likely result from isotopic fractionation at relatively low temperatures due to secondary processes, including: (1) the reduction of primary magmatic $\mathrm{SO}_{2}$ (likely $\delta^{34} \mathrm{~S} \sim 0 \pm$ $2 \%$,) to $\mathrm{H}_{2} \mathrm{~S}$ (Vinogradov, 1958; Thode et al., 1961), and (2) the addition of biogenic sulfides generated through bacterial sulfate reduction (Giggenbach, 1996; Marini et al., 2011).

Carbon isotope partitioning between methane and its higher chain homologues (Fig. 8) has been used to identify the origin of the hydrocarbons (Sherwood Lollar et al., 2002, 2008; Proskurowski et al., 2008). This criterion can only be applied if the entire amount of methane and the $C_{2}+n$-alkanes derive from a common thermogenic source. The Mount Mageik hydrocarbons display a "thermogenic" trend that is typically observed for hydrocarbons that are derived from the thermal decomposition of organic matter, i.e. $\delta^{13} \mathrm{C}$ increases with the number of carbons constituting the hydrocarbons (Fig. 8). For Trident, methane occurs more enriched in ${ }^{13} \mathrm{C}$ than ethane (i.e. shows a carbon isotope reversal trend). Sherwood Lollar et al. (2002) suggested that such an isotopic reversal trend might be characteristic for abiogenically generated (i.e. without organic material) hydrocarbons. However, laboratory experiments revealed that abiogenic hydrocarbons are not always characterized by a carbon isotope reversal between methane and ethane (e.g., Taran et al., 2007, 2010; McCollom and Seewald, 2006). Moreover, it has been recognized that thermogenic hydrocarbons originating from a highly mature organic source can also exhibit a carbon isotope reversal between methane and ethane (e.g. Tilley and Muehlenbachs, 2013). As a consequence, the carbon isotope patterns observed for the Trident hydrocarbons may still be in agreement with a common thermogenic origin. Considering this, organic matter may have influenced the overall gas composition observed at both volcanoes, as is also indicated from field observations (see above); high proportions of $\mathrm{CH}_{4}, \mathrm{H}_{2}, \mathrm{H}_{2} \mathrm{~S}$, and $\mathrm{CO}$; and the correlation plot between $\mathrm{CO}_{2} /{ }^{3} \mathrm{He}$ and $\delta^{13} \mathrm{C}^{-} \mathrm{CO}_{2}$ (Fig. $6 \mathrm{~d}$ ).

5.3. Temporal variations in the chemical and isotopic composition of measured gases

When the composition of Mount Mageik's gas emissions is compared with previous gas samples, several similarities and differences are observed. First, the ${ }^{3} \mathrm{He} /{ }^{4} \mathrm{He}$ ratio measured at Mount Mageik in $2013\left(7.56 R_{A}\right)$ is similar to measurements by Symonds et al. (2003a) (7.5-7.6 $\mathrm{R}_{\mathrm{A}}$ ) carried out between 1995 and 1998 (Fig. 6b). This indicates that magma degassing in Mount Mageik's subsurface has persisted since the mid 1990's. The fumarole samples collected by Symonds et al. (2003b) between 1995 and 1998 found consistent $\mathrm{CO}_{2} / \mathrm{H}_{2} \mathrm{~S}$ ratios of 9.6-10.5, which are $\sim 2-3$ times lower than the 2013 fumarole samples 
A)

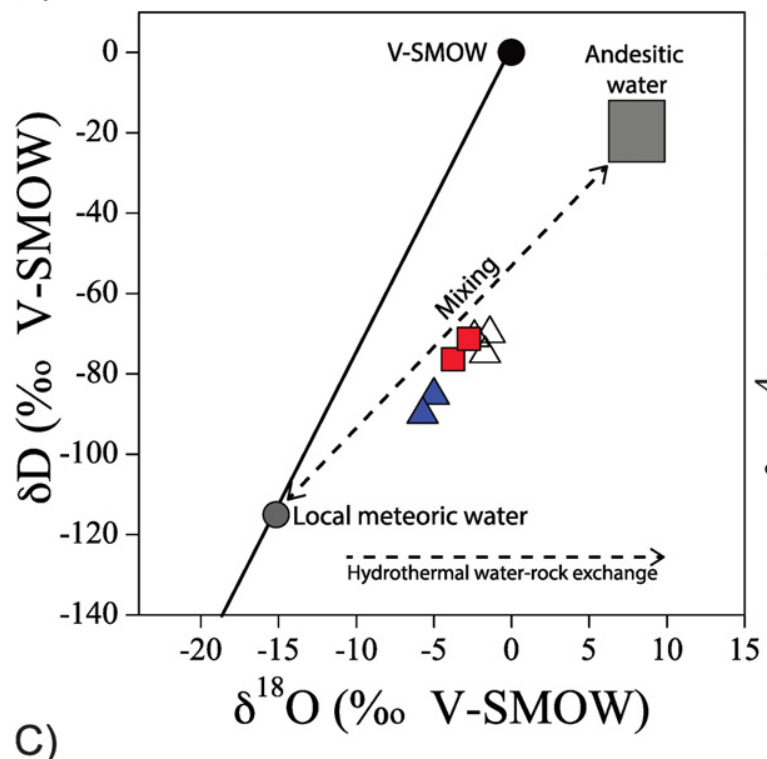

C)

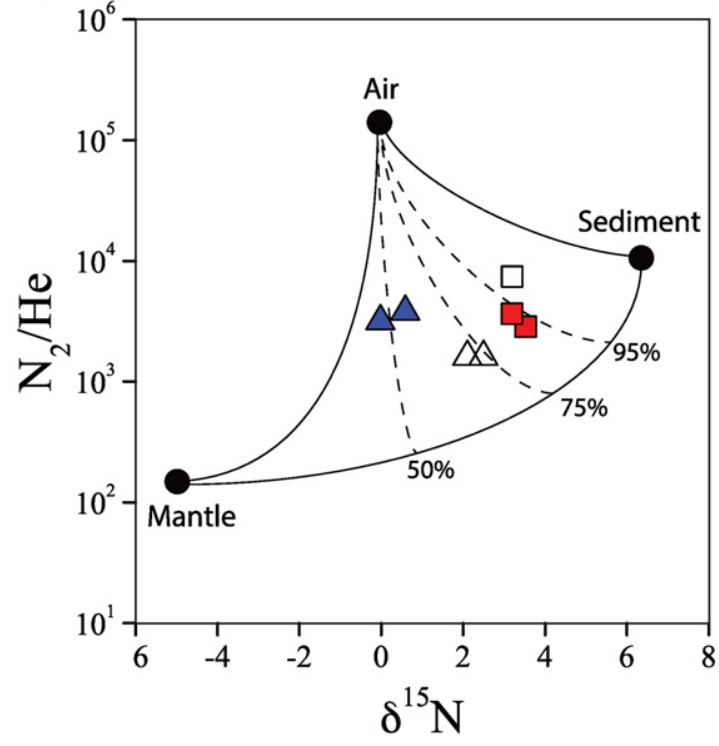

B)
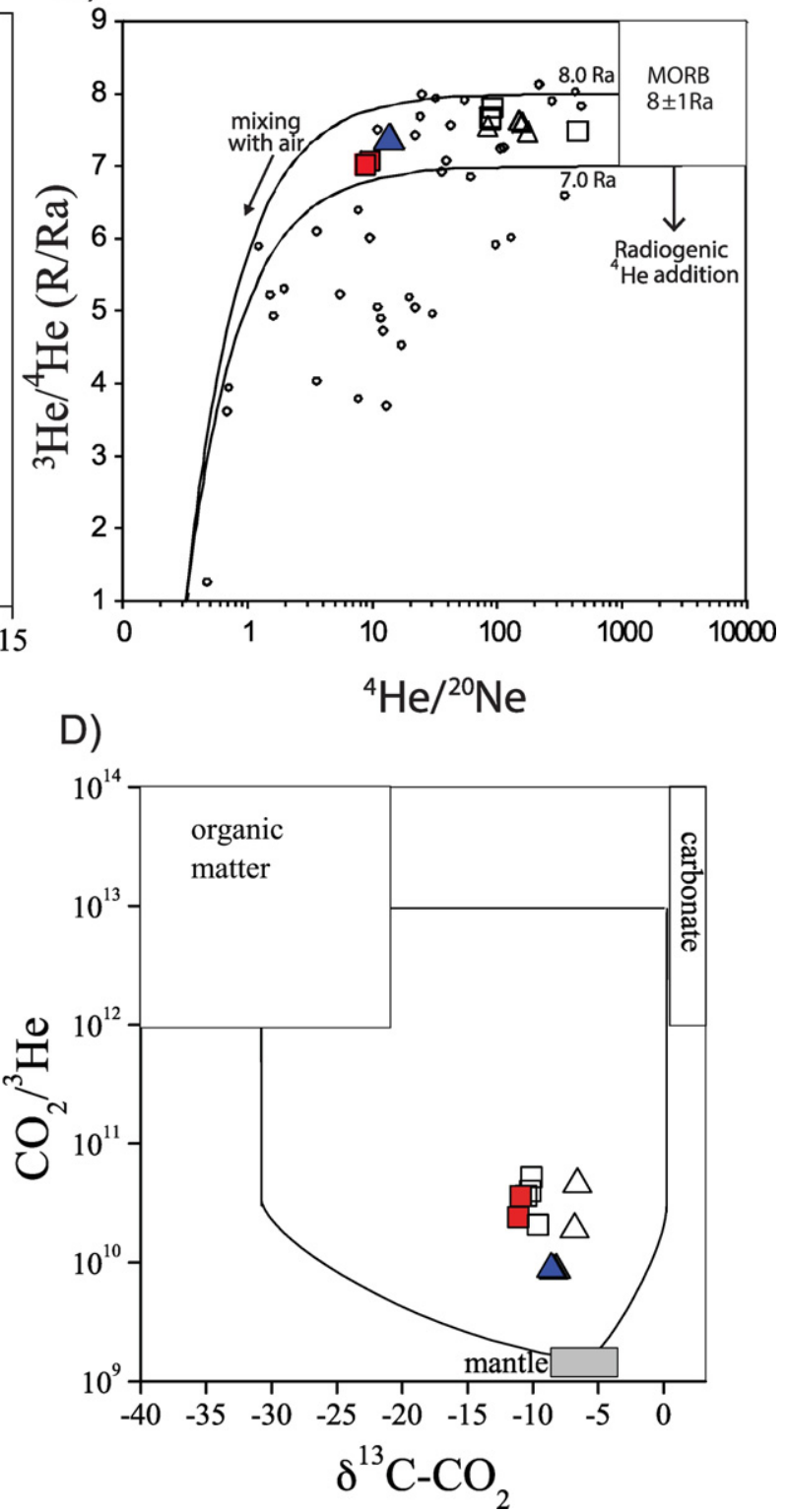

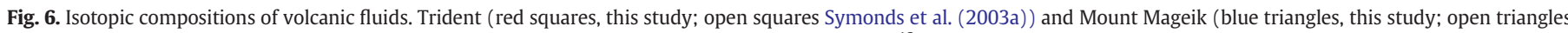

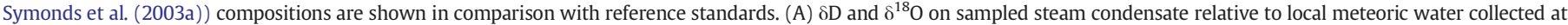

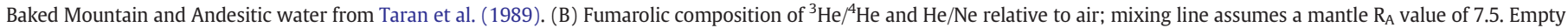

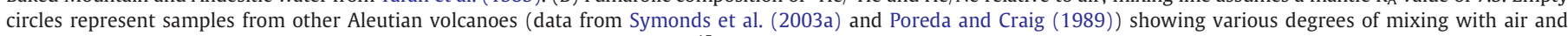

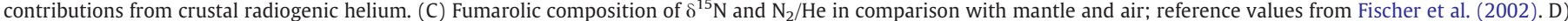
Fumarolic composition of $\delta^{13} \mathrm{C}^{-\mathrm{CO}_{2}}$ and $\mathrm{CO}_{2} /{ }^{3} \mathrm{He}$ relative to mantle, limestone and organic end-members; reference values from Sano and Marty (1995).

( 24-26), but are in fact quite similar to the 2013 MultiGAS measurements (6-9.5). When this observation is considered along with the differences between the fumarole samples and the MultiGAS measurements described above, it is likely that these discrepancies are simply due to spatial heterogeneities within the fumarole field, such that the fumaroles sampled in 2013 from the edge of the fumarole field have a larger meteoric influence then the fumarole samples analyzed by Symonds et al. (2003), as well as from the bulk plume measured by MultiGAS in 2013 (see Section 5.1.2 for details). This could also explain the higher extent of air contamination found in fluids collected in this work compared to those collected in 1995-1998 (Symonds et al., 2003a), as testified by the ${ }^{4} \mathrm{He} /{ }^{20} \mathrm{Ne}$ (Fig. 6b) and ${ }^{40} \mathrm{Ar} /{ }^{36} \mathrm{Ar}$ ratios measured in these samples. Considering the relatively stable ${ }^{3} \mathrm{He} /{ }^{4} \mathrm{He}$ ratios observed between the fumarole samples collected between 1995 and 1998 and the fumarole and MultiGAS measurements of 2013, we speculate that no significant change in Mount Mageik's magmatic-hydrothermal system has occurred since 1996. Over this 17 -year period an increase in the proportion of shallow crustal fluids (e.g. ${ }^{4} \mathrm{He}$ ) would be expected as magma degassed in the absence of magma recharge (e.g., Hilton et al., 1993; Nuccio et al., 2008; Correale et al., 2014; Di Piazza et al., 2015). This absence may suggest that periodic, small magma recharge events may have occurred in the past $\sim 15$ years beneath Mount Mageik to sustain these high ${ }^{3} \mathrm{He} /{ }^{4} \mathrm{He}$ ratios, as already highlighted by Symonds et al. (2003a) for other Aleutian volcanoes.

The fumarole composition from Trident measured in this study is similar to the composition measured by Symonds et al. (2003a), with a few differences. The ${ }^{3} \mathrm{He} /{ }^{4} \mathrm{He}$ ratios measured in 2013 at Trident (7.2-7.3 $\mathrm{R}_{\mathrm{A}}$ ) are appreciably lower than those measured in 1995-1998 by Symonds et al. (2003a), which varied from 7.5 to $7.8 R_{A}$ (Fig. $7 b$ ). 
A)

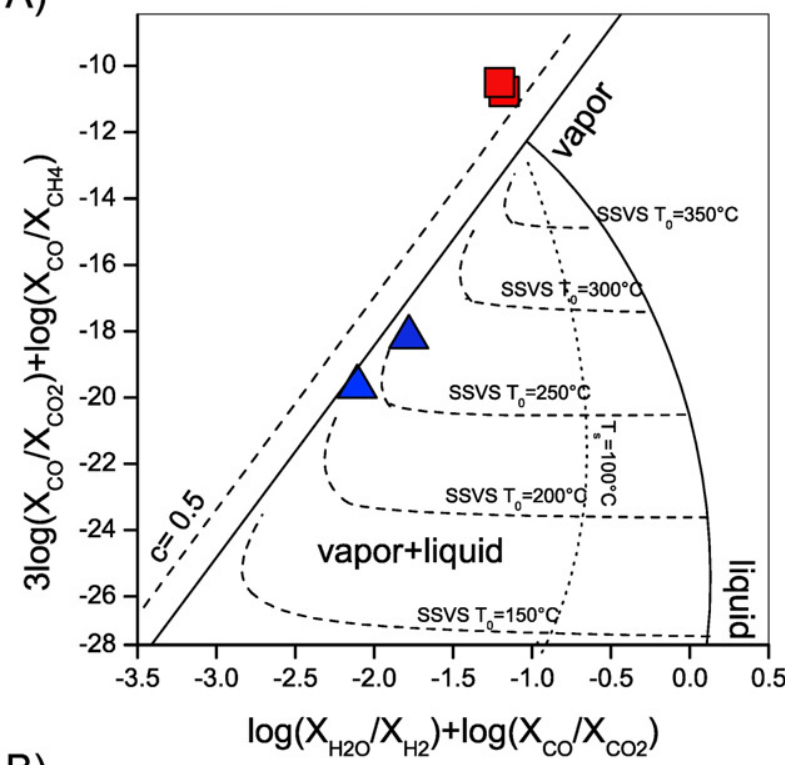

B)

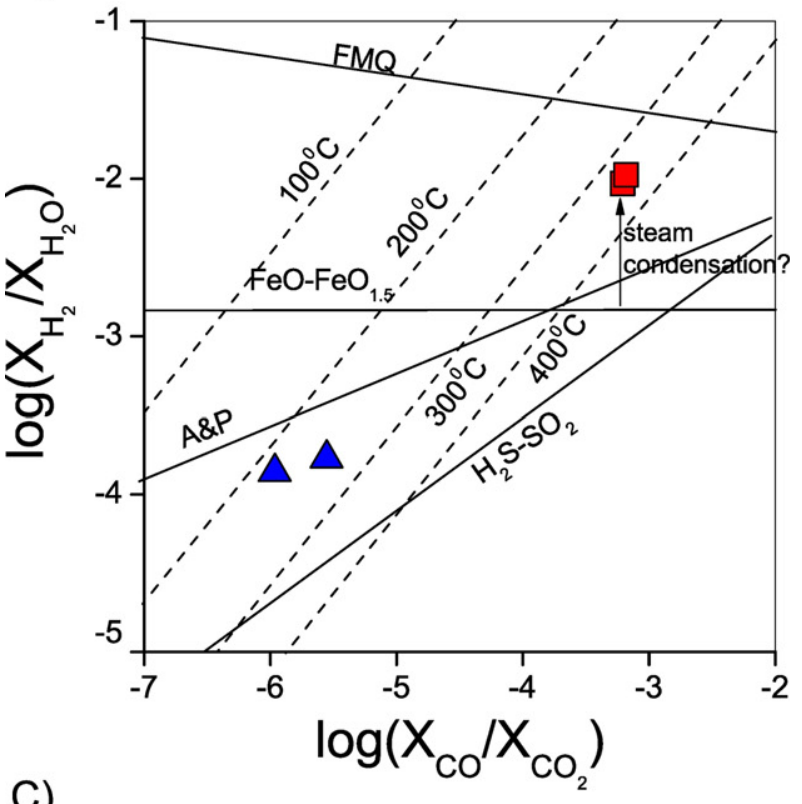

C)

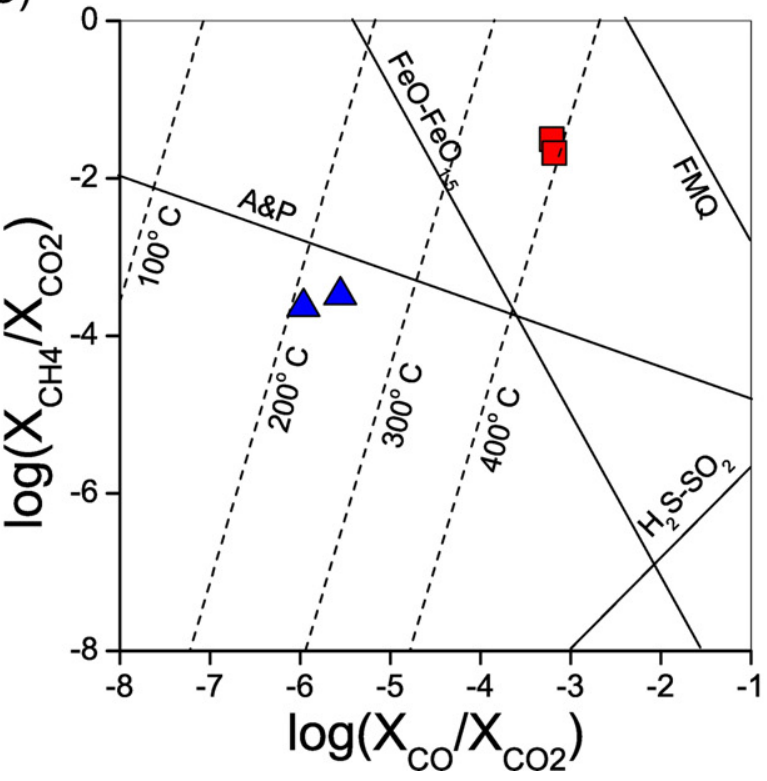

In contrast to what was observed at Mageik, this may indicate that magma feeding the fumaroles in the last $\sim 15$ years at Trident has undergone a gradual degassing and contamination by crustal-derived ${ }^{4} \mathrm{He}$ that led to the decrease of the mantle-like ${ }^{3} \mathrm{He} /{ }^{4} \mathrm{He}$ ratio (e.g., Hilton et al., 1993; Nuccio et al., 2008; Correale et al., 2014; Di Piazza et al., 2015). A second significant difference observed in Trident's fumarole chemistry is that the $\mathrm{CO}_{2} / \mathrm{H}_{2} \mathrm{~S}$ ratio measured in $2013(\sim 11)$ is somewhat lower than the range measured between 1994 and 1998 of $~ 15-$ 24 (Table 4). The consistent $\mathrm{CO}_{2} / \mathrm{H}_{2} \mathrm{~S}$ ratios measured in 2013 fumarole samples and MultiGAS measurements suggests that these changes are not explained by spatial heterogeneity within the fumarole field. The observed decrease in the $\mathrm{CO}_{2} / \mathrm{H}_{2} \mathrm{~S}$ ratio over time could suggest a decrease in the relative volume of hydrothermal water with respect to magmatic volatiles in Trident's subsurface over the past $\sim 17$ years (Fig. 6a). If this change were due to increased magmatic activity, we would expect additional chemical changes in fumarole chemistry. Considering the decrease in ${ }^{3} \mathrm{He} /{ }^{4} \mathrm{He}$ over time and absence of detectable $\mathrm{SO}_{2}$, we do not think it is likely that a significant magma recharge event occurred in recent years. One possible explanation to reconcile these observations is continued degassing of residual magma since the 1990 's combined with a decrease in hydrothermal system water-volume due to environmental factors such as decreased precipitation or increased permeability due to seismicity. Additional samples and/or data are required to better discriminate the factors controlling these observed changes.

5.4. Comparison of KVC volatile provenance with other Aleutian Arc Volcanoes

In Section 5.1, we conclude that, like other subduction zone volcanoes, both Mount Mageik and Trident reflect volatiles that originated from mantle, subducted slab and crustal sources. In Fig. 9, we plot the volatile provenance as calculated from the three component mixing model of Sano and Marty (1995) and following the example from Hilton et al. (2002) for Trident, Mount Mageik and other Aleutian Arc gas samples collected in this study and by Symonds et al. (2003b) and Motyka et al. (1993). In Fig. 9, both Trident and Mount Mageik gas emissions plot within the range of samples collected from other Aleutian Arc volcanoes, in the lower left apex of the ternary diagram, which represents predominance by carbonate minerals presumed to be sourced from the altered oceanic crust within the subducted slab. It is notable that this general gas composition is very similar to what has been observed from arc volcanoes around the globe (e.g. Hilton et al., 2002). Two exceptions to the carbonate dominance are seen in Aleutian samples, Okmok Volcano sampled 1981 and Douglas Volcano sampled in 1982 both by Motyka et al. (1993), where gas composition reflects a primarily mantle source. Of these two samples, the Okmok 1981 sample was likely collected within a few months of an eruption, which suggests that this deviation to greater mantle input could be related to volcanic unrest. We propose that diversions to greater mantle contribution along the left axis $(\mathrm{M}-\mathrm{C})$ of the ternary diagram are due to increased proportions of ${ }^{3} \mathrm{He}$ from mantle-derived magma and likely represent shallow magma emplacement, which overprints longer-term volatile cycling signatures (e.g. Hilton, 1996).

In addition to variations in proportions of mantle-derived gases modifying volcanic gas composition on the left-hand axis of Fig. 9, we also observe significant variability in gas composition along the bottom

Fig. 7. Traditional geothermometry model calculations. Model results for Trident (red squares) and Mount Mageik (blue triangles) hydrothermal systems are shown. (A) Redox independent geothermometry calculation of Chiodini and Marini (1998); (B) Fast reacting $\log \left(\mathrm{CO} / \mathrm{CO}_{2}\right)$ vs $\log \left(\mathrm{H}_{2} / \mathrm{H}_{2} \mathrm{O}\right)$ geothermometer of Giggenbach (1987); (C) Slowreacting $\log \left(\mathrm{CO} / \mathrm{CO}_{2}\right)$ vs $\log \left(\mathrm{CH}_{4} / \mathrm{CO}_{2}\right)$ geothermometer of Giggenbach (1987). Consistent, equilibrium temperatures of $\sim 200-250{ }^{\circ} \mathrm{C}$ are observed for Mount Mageik, while higher temperatures $\left(>350^{\circ} \mathrm{C}\right)$ and potentially disequilibrium conditions are observed for Trident. See text for details. 


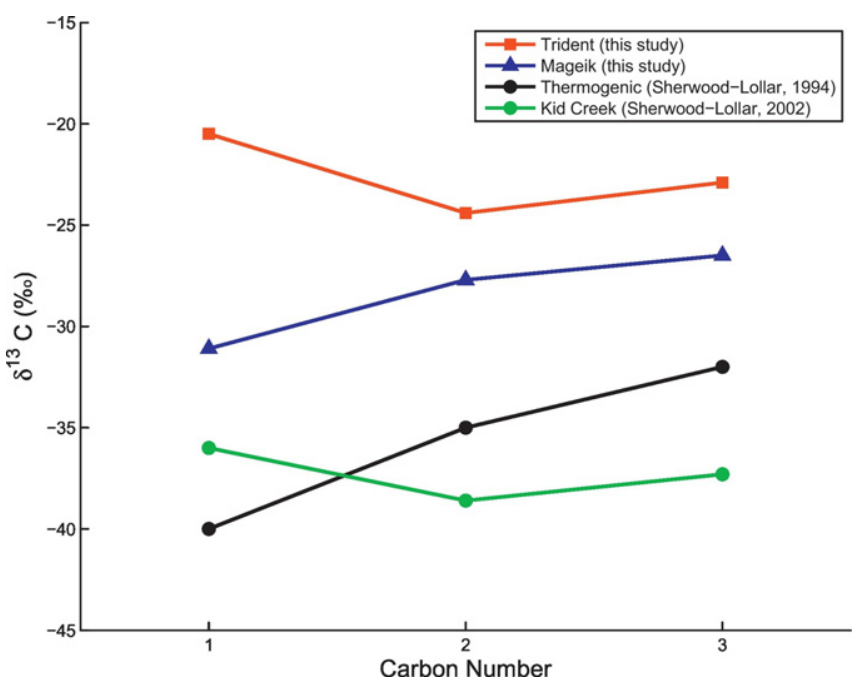

Fig. 8. Carbon isotope partitioning. $\mathrm{CH}_{4}(1), \mathrm{C}_{2} \mathrm{H}_{6}$ (2) and $\mathrm{C}_{3} \mathrm{H}_{8}(3) \delta^{13} \mathrm{C}$ values are shown for Trident (red squares) and Mount Mageik (blue triangles) fumarole compositions. When compared with "abiogenic" (e.g. Kid Creek) and "thermogenic" samples from Lollar et al. (1994, 2002), Trident's C isotopes reflect an apparent abiogenic signature, while Mount Mageik's C isotopes reflect a more typical thermogenic signature. See text for details.

axis from Aleutian Arc volcanoes, reflecting mixing between carbonate and organic sediment. For typical subduction zone volcanoes it would be assumed that both carbonate and organic sediment would be sourced from the subducted slab and overlying marine sediments, respectively. We have previously mentioned that sedimentary rocks are common within the KVC region, such that crustal rocks may be contributing to these sedimentary sources. Because the horizontal distance between the target volcanoes (within $\sim 17 \mathrm{~km}$ ) is significantly smaller than the depth to the subducted slab ( $85 \mathrm{~km}$ (England et al., 2004)), we would expect these volcanoes to reflect very similar volatile provenance compositions if the volatiles were sourced entirely from the subducted slab and mantle. Similarly, if the apparent variations in

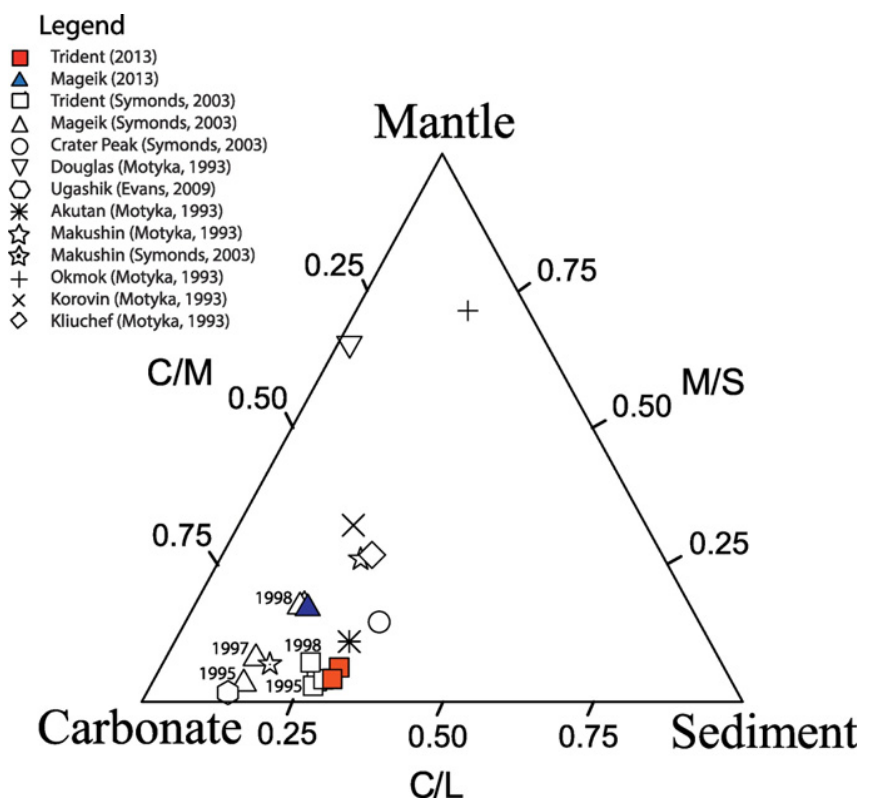

Fig. 9. Aleutian Arc volatile sources. Calculated volatile source compositions from the target volcanoes are shown relative to other Aleutian Arc volcanoes. End member compositions reflecting $\mathrm{C}$ (carbonate), $\mathrm{S}$ (sediment) and $\mathrm{M}$ (mantle) sources were calculated using the three component mixing model of Sano and Marty (1995). Figure after Hilton et al. (2002). See text for discussion.

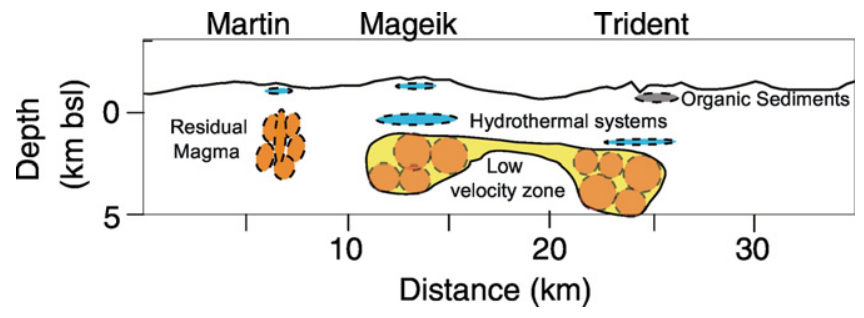

Fig. 10. Subsurface model of the Katmai Volcanic Cluster. This schematic model is based on interpretations from this study and previous geophysical studies. The yellow low-velocity zone is based on seismic tomography by Murphy et al. (2014). Small batches of magma (orange circles) are schematic only as inferred from gas geochemistry beneath Mount Martin, Mount Mageik and Trident Volcanoes. The speculated presence of organic matter based on this study is schematically illustrated. Hydrothermal system depths are from geothermometry model results described in Section 5.1. See text for further details.

carbonate and organic carbon within Aleutian Arc volcanoes were due entirely to deep processes (e.g. variable influx of organic marine sediment), we would expect to see spatial variations in predominance of organic vs. carbonate sources that correspond with latitude, which are not observed in the available gas samples. The significantly larger proportion of "organic carbon" in the Trident gas emissions relative to Mount Mageik when considering their very close spatial proximity $(\sim 10 \mathrm{~km})$, supports variations in crustal compositions or processes between the two volcanoes. Specifically, spatial heterogeneity in the shallow crust, for example, thermal decomposition of organic sediments in the crust beneath Trident volcano could comprise the primary source of "organic" gases released from Trident's fumarole field that is not observed at Mageik. Alternatively, variations in isotope fractionation processes between the two volcanoes could lead to different apparent carbon sources. These observations lead us to conclude that within the Aleutian Arc shallow crustal processes (e.g. isotopic fractionation and magma intrusion) and/or crustal volatile sources likely contribute to variability in apparent volatile provenance.

\subsection{Schematic subsurface model for KVC}

Based on our interpretations of subvolcanic conditions beneath the target volcanoes according to gas geochemistry data and interpretations from previous studies in the literature, we present a schematic subsurface model of the KVC region (Fig. 10). First, the close proximity of the target volcanoes to each other in comparison with the depth to the subducted slab makes it reasonable to assume an influx of relatively homogenous subducted fluids to volcanoes within the KVC. We therefore propose that much of the variation in surface gas emissions can be attributed to variations in shallow crustal subvolcanic conditions and/or processes. Secondly, the abundance of $\mathrm{CO}_{2}$ and $\mathrm{H}_{2} \mathrm{~S}$, and absence (Mount Mageik and Trident) or minor quantities of $\mathrm{HCl}$ and $\mathrm{SO}_{2}$ (Mount Martin, only), in the volcanic emissions from the target volcanoes supports the presence of well-developed subsurface hydrothermal systems. This is further supported by the presence of crater lakes within the summit craters of Mount Martin and Mount Mageik. Using the measured gas compositions and geothermometry tools described in Section 5.1.2 and assuming chemical equilibria, we calculate that Trident Volcano has subsurface hydrothermal systems at depth of $\sim 4 \mathrm{~km}$ below the surface ( sea-level and $3 \mathrm{~km}$ below sea level, respectively), whereas the kinetically fast gas species $\left(\mathrm{H}_{2}\right.$ and $\left.\mathrm{CO}\right)$ in the Mount Mageik gases seem to equilibrate at relatively shallow depth $(\sim 0.25 \mathrm{~km})$. The relatively deep hydrothermal system seen at Trident is consistent with a gradual deepening of seismicity observed from west to east within the KVC region (Murphy et al., 2014). We assume that crystallizing and degassing magma is providing heat and magmatic fluids to the overlying hydrothermal systems. We support previous interpretations that intrusion of small quantities of magma are common within the KVC region (Hildreth, 1987; Jolly et al., 2007) and envision several discrete 
magma batches degassing beneath each volcano. We note that this region is well-monitored by the AVO seismic network, such that we expect most significant and shallow magma intrusions to be observed seismically (e.g. Jolly and McNutt, 1999; De Angelis, 2006; O'Brien et al., 2012), that may in turn be linked to changes in gas composition. The significant quantities of $\mathrm{SO}_{2}$ degassing from Mount Martin and the relatively low $\mathrm{CO}_{2} / \mathrm{SO}_{2}$ ratio, are consistent with degassing of shallow magma, and may support seismic interpretations of magma intrusion in 2006 by O'Brien et al. (2012). Therefore the magmatic gases released from Mount Martin may represent residual degassing of the 2006 magma. Similarly, it is likely that the most recent shallow intrusion of significant quantities of magma beneath Mount Mageik occurred in association with the 1996 seismic swarm, as proposed by Jolly and McNutt (1999) based on seismic observations of low b-values and increasing depth of seismicity and supported by an increase in crater lake temperature by ten degrees between July 1995 and July 1997 (Jolly and McNutt, 1999). Therefore we speculate that the 1996 Mount Mageik magma continues to provide heat and magmatic gases to the hydrothermal system, and acknowledge that additional heat and gas may also be provided by more recent, small-volume and/or aseismic intrusions as suggested by similar ${ }^{3} \mathrm{He} /{ }^{4} \mathrm{He}$ ratios measured in 1998 (Symonds et al., 2003a) and in 2013 ( $7.5 \mathrm{R}_{\mathrm{A}}$; Fig. 7b). Based on our literature review we do not find seismic evidence to support shallow magma intrusion beneath Trident since the AVO seismic network was installed in 1995. An earthquake swarm near Trident volcano was observed in 2008 to migrate with time from NE of Trident's summit to the SW toward Katmai Pass, however based on the seismic data, Murphy et al. (2014) interpreted this swarm to represent migration of magmatic gases and/ or hydrothermal fluids. We conclude that if magma is present in the shallow crust beneath Trident Volcano, which we argue is likely due to the persistent fumarole emissions, active hydrothermal system, and high ${ }^{3} \mathrm{He} /{ }^{4} \mathrm{He}$ ratio of the fumarolic gases, we think that it was mostly likely emplaced prior to 1995 or was of sufficiently small volume to intrude aseismically.

\section{Conclusions}

We used the: (1) chemical and isotopic composition of fumarolic gases and steam condensate, (2) major species gas composition measured from coalesced fumaroles and/or crater lake degassing, and/or (3) the flux of volatiles from Mount Martin, Mount Mageik and Trident volcanoes, Alaska, to constrain volatile sources and characterize subvolcanic conditions within the Katmai Volcanic Cluster. The MORBlike ${ }^{3} \mathrm{He} /{ }^{4} \mathrm{He}$ ratios observed in Mount Mageik and Trident's fumarole emissions and moderate $\mathrm{SO}_{2}$ flux from Mount Martin, combined with gas compositions dominated by $\mathrm{H}_{2} \mathrm{O}, \mathrm{CO}_{2}$ and $\mathrm{H}_{2} \mathrm{~S}$ from all three volcanoes indicate magma degassing and active hydrothermal systems in the subsurface of the three target volcanoes. Mount Martin's gas emissions have the lowest $\mathrm{CO}_{2} / \mathrm{H}_{2} \mathrm{~S}$ ratio $(\sim 2-4)$ and highest $\mathrm{SO}_{2}$ flux $(\sim 75 \mathrm{t} / \mathrm{d})$ indicating that Mount Martin's emissions have a greater magmatic degassing component. This observation combined with seismic interpretations of magma intrusion in Mount Martin's subsurface in 2006, suggest that Mount Martin is home to the most recent (significant) shallow-crustal magma intrusion within the KVC. Below detection limit $\mathrm{SO}_{2}$ from both Mount Mageik and Trident indicate efficient scrubbing of acid magmatic gases consistent with a relatively low ratio of magmatic gases to hydrothermal waters. Assuming geochemical equilibria in the subsurface beneath Mount Mageik and Trident, we estimate the depth of the hydrothermal reservoirs of 0.2 and $4 \mathrm{~km}$, respectively, which we assume overly the magmatic system. Carbon, helium, and nitrogen isotopes from Mount Mageik and Trident indicate mixtures of crustal, mantle and subducted volatile-sources, with a predominance of sedimentary sources from the subducted slab or crust. When volatile provenances for the target volcanoes are compared to other Aleutian Arc volcanoes, a predominance of volatiles sourced from carbonate rocks is apparent though significant scatter is observed. Considering the close proximity of the target volcanoes in comparison with the depth to the subducted slab, we speculate that Aleutian Arc volatiles are fed by a relatively homogeneous subducted fluid composition and that much of the apparent variability in volatile provenance can be explained by shallow crustal volatile sources and/or processes (e.g. shallow magma intrusion and/or isotopic fractionation).

\section{Acknowledgements}

This project was supported by the National Science Foundation (GeoPRISMS) award \#1250148. This project was successful due to the combined efforts of numerous individuals and organizations, to whom we are most grateful. In particular, the authors would like to thank: helicopter pilot Sam Egli, and the staff of Egli Air Haul, for their commitment to safety, excellent service, and continual support that made this work successful even under challenging conditions; the Alaska Volcano Observatory, especially John Paskievitch and Dane Ketner for significant logistical, equipment and field support that enabled us to deploy and retrieve our campaign instruments; the National Park Service, and especially the employees of the Katmai National Park, for their assistance with permitting and project logistics, in addition to their support of science; Max Kaufman from the UAF Geophysical Institute/Alaska Volcano Observatory, who assisted with NOVAC station installations; Deb Bergfeld and Bill Evans, from the USGS, who provided water sampling equipment and analysis; Orlando Vaselli, from the University of Florence, who provided analysis of $\mathrm{CO}_{2}$ isotopes; Mariano Tantillo, from the INVG Palermo, who helped with the He isotope measurements; Tom Trainor, Sarah Hayes, Bill Simpson, Emily Reiter and Jacy Pietsch, of the UAF Department of Chemistry and Biochemistry, who provided laboratory space and equipment that made this work possible; David Fee for guidance with Matlab programming; and Mike West for postdoctoral mentoring. TL would like to acknowledge travel support from the Deep Carbon Observatory to present results of this work at AGU conferences in 2014 and 2015. This manuscript benefited significantly from constructive scientific discussions with Giovanni Chiodini and reviews by Yuri Taran, Peter Kelly and Thor Hansteen.

\section{References}

Aiuppa, A., Frederico, C., Guidice, G., Gurrieri, S., 2005. Chemical mapping of a fumarolic field: La Fossa Crater, Vulcano Island (Aeolian Islands, Italy). Geophys. Res. Lett. 32, L13309.

Aiuppa, A., Bertagnini, A., Métrich, N., Moretti, R., Di Muro, A., Liuzzo, M., Tamburello, G., 2010. A model of degassing for Stromboli volcano. Earth Planet. Sci. Lett. 295, 195-204.

Aiuppa, A, Giudice, G. Liuzzo, M., Tamburello, G, Allard, P., Calabrese, S. Chaplygin, I, McGonigle, A.J.S., Taran, Y., 2012. First volatile inventory for Gorely volcano. Kamchatka. Geophys. Res. Lett. 39.

Aiuppa, A., Robidoux, P., Tamburello, G., Conde, V., Galle, B., Avard, G., Bagnato, E., De Moor, J.M., Martínez, M., Muñóz, A., 2014. Gas measurements from the Costa RicaNicaragua volcanic segment suggest possible along-arc variations in volcanic gas chemistry. Earth Planet. Sci. Lett. 407, 134-147.

Aiuppa, A., Fischer, T.P., Plank, T., Robidoux, P., Di Napoli, R., 2017. Along-arc, inter-arc and arc-to-arc variations in volcanic gas CO 2/S T ratios reveal dual source of carbon in arc volcanism. Earth Sci. Rev.

Baertschi, P., 1976. Absolute ${ }^{18} \mathrm{O}$ content of standard mean ocean water. Earth Planet. Sci. Lett. 31, 341-344.

Caliro, S., Viveiros, F., Chiodini, G., Ferreira, T., 2015. Gas geochemistry of hydrothermal fluids of the S. Miguel and Terceira Islands, Azores. Geochim. Cosmochim. Acta 168, 43-57.

Chiodini, G., Cioni, R., 1989. Gas geobarometry for hydrothermal systems and its application to some Italian geothermal areas. Appl. Geochem 4 (5), 465-472.

Chiodini, G., Marini, L., 1998. Hydrothermal gas equilibria: the $\mathrm{H}_{2} \mathrm{O}-\mathrm{H}_{2}-\mathrm{CO}_{2}-\mathrm{CO}-\mathrm{CH}_{4}$ system. Geochim. Cosmochim. Acta 62, 2673-2687.

Chiodini, G., Caliro, S., Lowenstern, J., Evans, W., Bergfeld, D., Tassi, F., Tedesco, D., 2012. Insights from fumarole gas geochemistry on the origin of hydrothermal fluids on the Yellowstone Plateau. Geochim. Cosmochim. Acta 89, 265-278.

Coombs, M., Eichelberger, J.C., Rutherford, M.J., 2000. Magma storage and mixing conditions for the 1953-1974 eruptions of Southwest Trident volcano, Katmai National Park, Alaska. Contrib. Mineral. Petrol. 140, 99-118.

Correale, A., Paonita, A., Martelli, M., Rizzo, A., Rotolo, S.G., Corsaro, R.A., Di Renzo, V., 2014 A two-component mantle source feeding Mt. Etna magmatism: insights from the geochemistry of primitive magmas. Lithos 184:243-258. https://oi.org/10.1016/ j.lithos.2013.10.038 
Craig, H., 1957. Isotopic standards for carbon and oxygen and correction factors for massspectrometric analysis of carbon dioxide. Geochim. Cosmochim. Acta 12 (1), 133-149.

Craig, H., 1963. The isotopic geochemistry of water and carbon in geothermal areas. Nucl. Geol. Geotherm. Areas 17-53.

De Angelis, S., 2006. Analyses of unusual long-period earthquakes with extended coda recorded at Katmai National Park, Alaska, USA. Geophys. Res. Lett 33 (7).

de Moor, J.M., Fischer, T.P., Sharp, Z.D., King, P.L., Wilke, M., Botcharnikov, R.E., Cottrell, E., Zelenski, M., Marty, B., Klimm, K., Rivard, C., 2013. Sulfur degassing at Erta Ale (Ethiopia) and Masaya (Nicaragua) volcanoes: implications for degassing processes and oxygen fugacities of basaltic systems. Geochem. Geophys. Geosyst. 14 (10), 4076-4108.

de Moor, J.M., et al., 2016. Short-period volcanic gas precursors to phreatic eruptions: insights from Poás Volcano. Costa Rica. Earth Planet. Sci. Lett 442, 218-227.

D'Amore, F., Panichi, C., 1980. Evaluation of deep temperatures of hydrothermal systems by a new gas geothermometer. Geochim. Cosmochim. Acta 44 (3), 549-556.

Di Napoli, R., Aiuppa, A., Bergsson, B., Ilyinskaya, E., Pfeffer, M.A., Guðjónsdóttir, S.R., Valenza, M., 2016. Reaction path models of magmatic gas scrubbing. Chem. Geol. 420, 251-269.

Di Piazza, A., Rizzo, A.L., Barberi, F., Carapezza, M.L., De Astis, G., Romano, C., Sortino, F., 2015. Geochemistry of the mantle source and magma feeding system beneath Turrialba volcano, Costa Rica. Lithos 232, 319-335.

Dixon, J.P., Stihler, S.D., Power, J.A., Haney, M., Parker, T., Searcy, C.K., Prejean, S., 2013. Catalog of Earthquake Hypocenters at Alaskan Volcanoes: January 1 Through December 31, 2012. U.S. Geological Survey Data Series 789 pp. 1-92.

Doukas, M., 2002. A New Method for GPS-based Wind Speed Determinations During Airborne Volcanic Plume Measurements. U.S. Geological Survey (Open-File Report 02395).

Doukas, M., McGee, K., 2007. A Compilation of Gas Emission-rate Data From Volcanoes of Cook Inlet (Spurr, Crater Peak, Redoubt, Illiamna, and Augustine) and Alaska Peninsula (Douglas, Fourpeaked, Griggs, Mageik, Martin, Peulik, Ukinrek Maars, and Veniaminof), Alaska, From 1995-2006. U.S. Geological Survey (Open-File Report 07-1400).

Edmonds, M., Herd, R., Galle, B., Oppenheimer, C., 2003. Automated, high time-resolution measurements of $\mathrm{SO}_{2}$ flux at Soufriere Hills Volcano, Montserrat. Bull. Volcanol. 65, 578-586.

England, P., Engdahl, R., Thatcher, W., 2004. Systematic variation in the depths of slabs beneath arc volcanoes. Geophys. J. Int. 156 (2), 377-408.

Epstein, S., Mayeda, T., 1953. Variation of the ${ }^{18} \mathrm{O} /{ }^{16} \mathrm{O}$ ratio in natural waters. Geochim. Cosmochim. Acta 4, 213-224.

Evans, W.C., et al., 1998. Gas-water interaction at Mammoth Mountain volcano, California, USA. Water-rock Interaction: Proceedings of the 9th International Symposium on Water-Rock Interaction-WRI-9, Taupo, New Zealand, 30 March-3 April 1998 Vol. 9. Taylor \& Francis.

Fenner, C.N., 1930. Mount Katmai and Mount Mageik (K. Reimer).

Fiebig, J., Hofmann, S., Tassi, F., D'Alessandro, W., Vaselli, O., Woodland, A.B., 2015. Isotopic patterns of hydrothermal hydrocarbons emitted from Mediterranean volcanoes. Chem. Geol. 396, 152-163.

Fischer, T.P., Giggenbach, W.F., Sano, Y., Williams, S.N., 1998. Fluxes and sources of volatiles discharged from Kudryavy, a subduction zone volcano, Kurile Islands. Earth Planet. Sci. Lett. 160, 81-96.

Fischer, T.P., Hilton, D.R., Zimmer, M.M., Shaw, A.M., Sharp, Z.D., Walker, J.A., 2002. Subduction and recycling of nitrogen along the Central American margin. Science 297, 1154-1157.

Galle, B., Oppenheimer, C., Geyer, A., McGonigle, A., Edmonds, M., Horrocks, L., 2002. A miniaturised ultraviolet spectrometer for remote sensing of $\mathrm{SO}_{2}$ fluxes: a new tool for volcano surveillance. J. Volcanol. Geotherm. Res. 119, 241-254.

Galle, B., Johansson, M., Rivera, C., Zhang, Y., Kihlman, M., Kern, C., Lehmann, T., Platt, U. Arellano, S., Hidalgo, S., 2010. Network for Observation of Volcanic and Atmospheric Change (NOVAC) - a global network for volcanic gas monitoring: network layout and instrument description. J. Geophys. Res. 115, D05304.

Gerlach, T.M., 2003. Elevation effects in volcano applications of the COSPEC. Geol. Soc. London Spec. Publ. 213 (1), 169-175.

Gerlach, T.M., 2004. Volcanic sources of tropospheric ozone-depleting trace gases. Geochem. Geophys. 5 (9).

Giggenbach, W., 1975. A simple method for the collection and analysis of volcanic gas samples. Bull. Volcanol. 39, 132-145.

Giggenbach, W., 1982. The chemical and isotopic composition of gas discharges from New Zealand andesitic volcanoes. Bull. Volcanol. 45 (3), 253-255.

Giggenbach, W., 1987. Redox processes governing the chemistry of fumarolic gas discharges from White Island, New Zealand. Appl. Geochem. 2, 143-161.

Giggenbach, W.F., 1992a. Isotopic shifts in waters from geothermal and volcanic systems along convergent plate boundaries and their origin. Earth Planet. Sci. Lett. 113, 495-510.

Giggenbach, W.F., 1992b. The composition of gases in geothermal and volcanic systems as a function of tectonic setting. Water-Rock Interact. 2, 873-878.

Giggenbach, W., 1996. Chemical composition of volcanic gases. In: Scarpa, R., Tilling, R. (Eds.), Monitoring and Mitigation of Volcano Hazards. Springer, Berlin, pp. 221-256.

Giggenbach, W., 1997. The origin and evolution of fluids in magmatic-hydrothermal systems. In: Barnes, H.L. (Ed.), Geochemistry of Hydrothermal Ore Deposits. John Wiley and Sons.

Giggenbach, W.F., Matsuo, S., 1991. Evaluation of results from Second and Third IAVCEI field workshops on volcanic gases, Mt Usu, Japan, and White Island, New Zealand. Appl. Geochem. 6 (2), 125-141.

Graham, D.W., 2002. Noble gas isotope geochemistry of mid-ocean ridge and ocean island basalts: characterization of mantle source reservoirs. Rev. Mineral. Geochem. 47 (1), 247-317.
Gunawan, H., Caudron, C., Pallister, J., Primulyana, S., Christenson, B., McCausland, W., Van Hinsberg, V., Lewicki, J., Rouwet, D., Kelly, P., Kern, C., Werner, C., Johnson, J.B., Utami, S.B., Syahbana, D.K., Saing, U., Suparjan, B.H.Purwanto, Sealing, C., Martinez Cruz, M. Maryanto, S., Bani, P., Laurin, A., Schmid, A., Bradley, K., Nandaka, G.M.A., Hendrasto, M., 2016. New insights into Kawah Ijen's volcanic system from the wet volcano workshop experiment. Geological Society, London, Special Publications 437. https:// doi.org/10.1144/SP437.7.

Hagemann, R., Nief, G., Roth, E., 1970. Absolute isotopic scale for deuterium analysis of natural waters, absolute $\mathrm{D} / \mathrm{H}$ ratio for SMOW1. Tellus 22 (6), 712-715.

Hildreth, W., 1987. New perspectives on the eruption of 1912 in the valley of ten thousand smokes, Katmai National Park. Alaska. Bull. Volcanol 49 (5), 680-693.

Hildreth, W., Fierstein, J., 2000. Katmai volcanic cluster and the great eruption of 1912. Geol. Soc. Am. Bull. 112 (10), 1594-1620.

Hildreth, W., Fierstein, J., 2012. The Novarupta-Katmai eruption of 1912 - largest eruption of the twentieth century: centennial perspectives. US Geol. Surv. Prof. Pap. 1791, 179-191.

Hildreth, W., Fierstein, J., Lanphere, M.A., Siems, D.F., 2001. Trident volcano: four contiguous stratocones adjacent to Katmai Pass, Alaska Peninsula. US Geol. Surv. Prof. Pap. $1678,153-180$.

Hilton, D.R., 1996. The helium and carbon isotope systematics of a continental geotherma system: results from monitoring studies at Long Valley caldera (California, USA) Chem. Geol. 127 (4), 269-295.

Hilton, D.R., Hammerschmidt, K., Teufel, S., Friedrichsen, H., 1993. Helium isotope characteristics of Andean geothermal fluids and lavas. Earth Planet. Sci. Lett. 120 (3-4): 265-282. http://dx.doi.org/10.1016/0012-821X(93)90244-4.

Hilton, D.R., Fischer, T.P., Marty, B., 2002. Noble gases and volatile recycling at subduction zones. Rev. Mineral. Geochem. 47 (1), 319-370.

Hoefs, J., 1997. Stable Isotope Geochemistry. 4th, Completely Revised, updated, and Enlarged Edition.

Holloway, J.R., 1984. Graphite- $\mathrm{CH}_{4}-\mathrm{H}_{2} \mathrm{O}-\mathrm{CO}_{2}$ equilibria at low-grade metamorphic conditions. Geology 12, 455-458.

Javoy, M., Pineau, F., Delorme, H., 1986. Carbon and nitrogen isotopes in the mantle. Chem. Geol. 57 (1-2), 41-62.

Jensen, M.L., Nakai, N., 1962. Sulfur isotope meteorite standards, results and recommendations. Biogeochemistry of Sulfur Isotopes. NSF Symposium, pp. 30-35.

Jolly, A.D., McNutt, S.R., 1999. Seismicity at the volcanoes of Katmai National Park, Alaska: July 1995-December 1997. J. Volcanol. Geotherm. Res. 93 (3-4), 173-190.

Jolly, A.D., Moran, S.C., McNutt, S.R., Stone, D.B., 2007. Three-dimensional P-wave velocity structure derived from local earthquakes at the Katmai group of volcanoes, Alaska. J. Volcanol. Geotherm. Res. 159, 326-342.

Junk, G., Svec, H.J., 1958. The absolute abundance of the nitrogen isotopes in the atmosphere and compressed gas from various sources. Geochim. Cosmochim. Acta 14 (3), 234-243.

Keller, A.S., Reiser, H.N., 1959. Geology of the Mount Katmai Area Alaska. Geol. Surv. Bull. 1058-G.

Kienle, J., 1970. Gravity traverses in the Valley of Ten Thousand Smokes, Katmai Nationa Monument, Alaska. J. Geophys. Res. 75 (32), 6641-6649.

Lollar, B.S., O'Nions, R.K., Ballentine, C.J., 1994. Helium and neon isotope systematics in carbon dioxide-rich and hydrocarbon-rich gas reservoirs. Geochim. Cosmochim. Acta 58 (23), 5279-5290.

Lollar, B.S., Westgate, T.D., Ward, J.A., Slater, G.F., Lacrampe-Couloume, G., 2002. Abiogenic formation of alkanes in the Earth's crust as a minor source for global hydrocarbon reservoirs. Nature 416 (6880), 522-524.

Lollar, B.S., Lacrampe-Couloume, G., Voglesonger, K., Onstott, T.C., Pratt, L.M., Slater, G.F 2008. Isotopic signatures of $\mathrm{CH}_{4}$ and higher hydrocarbon gases from Precambrian Shield sites: a model for abiogenic polymerization of hydrocarbons. Geochim. Cosmochim. Acta 72 (19), 4778-4795.

Lopez, T.M., Tassi, F., Capecchiacci, F., Fiebig, J., Rizzo, A., Caliro, S., 2017. Fumarole composition of Mount Mageik and Trident Volcano, July 2013. EarthChem Library https:// doi.org/10.1594/IEDA/100598.

Mamyrin, B., Tolstikhin, I., 1984. Helium isotopes in nature. Developments in Geochemistry. 288. Elsevier, E. S. Ltd. Amsterdam.

Marini, L., Moretti, R., Accornero, M., 2011. Sulfur isotopes in magmatic-hydrotherma systems, melts, and magmas. Rev. Mineral. Geochem. 73 (1), 423-492.

Marty, B., Lenoble, M., Vassard, N., 1995. Nitrogen, helium and argon in basalt: a static mass spectrometry study. Chem. Geol. 120 (1-2), 183-195.

McCollom, T.M., Seewald, J.S., 2006. Carbon isotope composition of organic compounds produced by abiotic synthesis under hydrothermal conditions. Earth Planet. Sci. Lett. 243 (1), 74-84.

Moran, S.C., 2003. Multiple seismogenic processes for high-frequency earthquakes at Katmai National Park, Alaska: evidence from stress tensor inversions of fault-plane solutions. Bull. Seismol. Soc. Am. 93 (1), 94-108.

Motegrossi, G., Tassi, F., Vaselli, O., Buccianiti, A., Garofalo, K., 2001. Sulfur species in volcanic gases. Anal. Chem. 73 (15), 3709-3715.

Motyka, R.J., Liss, S.A., Nye, C.J., Moorman, M.A., 1993. Geothermal Resources of the Aleutian Arc. Alaska Department of Natural Resources, Division of Geological \& Geophysical Surveys.

Murphy, R., Thurber, C., Prejean, S., Bennington, N., 2014. Three-dimensional seismic velocity structure and earthquake relocations at Katmai, Alaska. J. Volcanol. Geotherm. Res. 276, 121-131.

Nelson, S.T., 2000. A simple, practical methodology for routine VSMOW/SLAP normalization of water samples analyzed by continuous flow methods. Rapid Commun. Mass Spectrom. 14, 1044-1046.

Nuccio, P.M., Paonita, A., Rizzo, A., Rosciglione, A., 2008. Elemental and isotope covariation of nobel gases in mineral phases from Etnean volcanics erupted during 2001-2005 and genetic relation with peripheral gas discharges. Earth Planet. Sci. Lett. 272, 683-690. 
O'Brien, J.F., Roman, D.C., Dixon, J.P., Power, J.A., Arnold, R.A., 2012. Multiple causes for non-eruptive seismic swarms at Mt. Martin, Katmai Volcanic Cluster, Alaska (20042008). J. Volcanol. Geotherm. Res. 229-230, 13-22.

Pineau, F., Javoy, M., 1983. Carbon isotopes and concentrations in mid-oceanic ridge basalts. Earth Planet. Sci. Lett. 62 (2), 239-257.

Plank, T., Langmuir, C.H., 1998. The chemical composition of subducting sediment and its consequences for the crust and mantle. Chem. Geol. 145 (3), 325-394.

Platt, U., Stutz, J., 2008. Differential Optical Absorption Spectroscopy Principles and Applications. Springer-Verlag, Berlin - Heidelberg.

Poreda, R., Craig, H., 1989. Helium isotope ratios in circum-Pacific volcanic arcs. Nature $338,473-478$

Proskurowski, G., Lilley, M.D., Seewald, J.S., Früh-Green, G.L., Olson, E.J., Lupton, J.E., Sylva, S.P., Kelley, D.S., 2008. Abiogenic hydrocarbon production at Lost City hydrotherma field. Science 319 (5863), 604-607.

Rizzo, A., Barberi, F., Carapezza, M.L., Di Piazza, A., Francalanci, L., Sortino, F., D'Alessandro, W., 2015. New mafic magma refilling a quiescent volcano: evidence from $\mathrm{He}-\mathrm{Ne}-\mathrm{Ar}$ isotopes during the 2011-2012 unrest at Santorini, Greece. Geochem. Geophys. https://doi.org/10.1002/2014GC005653.

Robidoux, P., Aiuppa, A., Rotolo, S.G., Rizzo, A.L., Hauri, E.H., Frezzotti, M.L., 2017. Volatile contents of mafic-to-intermediate magmas at San Cristóbal volcano in Nicaragua. Lithos 272-273, 147-163.

Sano, Y., Marty, B., 1995. Origin of carbon in fumarolic gas from island arcs. Chem. Geol. $119,265-274$.

Shinohara, H., 2005. A new technique to estimate volcanic gas composition: plume measurements with a portable multi-sensor system. J. Volcanol. Geotherm. Res. 143, 319-333.

Shinohara, H., Yoshikawa, S., Miyabuchi, Y., 2015. Degassing Activity of a Volcanic Crater Lake: Volcanic Plume Measurements at the Yudamari Crater Lake, Aso Volcano, Japan. In: Rouwet, D., Christenson, B., Tassi, F., Vandemeulebrouck, J. (Eds.), Volcanic Lakes. Advances in Volcanology. Springer, Berlin, Heidelberg.

Snyder, G., Poreda, R., Hunt, A., Fehn, U., 2001. Regional variations in volatile composition: isotopic evidence for carbonate recycling in the Central American volcanic arc. Geochem. Geophys. 2

Symonds, R., Rose, W., Bluth, G., Gerlach, T., 1994. Volcanic gas studies: methods, results, and applications. In: Carroll, M., Holloway, J. (Eds.), Volatiles in Magmas. Mineralogical Society of America, Fredericksburg, pp. 1-63.

Symonds, R.B., Gerlach, T.M., Reed, M.H., 2001. Magmatic gas scrubbing: implications for volcano monitoring. J. Volcanol. Geotherm. Res. 108 (1-4), 303-341.
Symonds, R.B., Janik, C., Evans, W., Ritchie, B., Counce, D., Poreda, R., Iven, M., 2003a. Scrubbing masks magmatic degassing during response at cascades-range and Aleutian-Arc volcanoes. U.S. Geological Survey Open-File Report 03-435.

Symonds, R.B., Poreda, R.J., Evans, W.C., Janik, C.J., 2003b. Mantle and crustal sources of carbon, nitrogen, and noble gases in Cascade-Range and Aleutian-Arc volcanic gases. U.S. Geological Survey Open-File Report 03-436.

Tamburello, G., 2015. Ratiocalc: software for processing data from multicomponent volcanic gas analyzers. Comput. Geosci. 82, 63-67.

Tamburello, G., Agusto, M., Caselli, A., Tassi, F., Vaselli, O., Calabrese, S., Chiodini, G., 2015. Intense magmatic degassing through the lake of Copahue volcano, 2013-2014. J. Geophys. Res. Solid Earth 120 (9), 6071-6084.

Taran, Y.A., 2009. Geochemistry of volcanic and hydrothermal fluids and volatile budget of the Kamchatka-Kuril subduction zone. Geochim. Cosmochim. Acta 73 (4), 1067-1094.

Taran, Y., Pokrovsky, B.G., Dubik, Y.M., 1989. Isotopic composition and origin of water in andesitic magmas. Dokl. Acad. Sci. USSR 304, 440-443.

Taran, Y., Fischer, T.P., Cienfuegos, E., Morales, P., 2002. Geochemistry of hydrothermal fluids from an intraplate ocean island: Everman volcano, Socorro Island, Mexico. Chem. Geol. 188 (1), 51-63.

Taran, Y.A., Kliger, G.A., Sevastianov, V.S., 2007. Carbon isotope effects in the open-system Fischer-Tropsch synthesis. Geochim. Cosmochim. Acta 71 (18), 4474-4487.

Taran, Y.A, Varley, N.R., Inguaggiato, S., Cienfuegos, E., 2010. Geochemistry of $\mathrm{H}_{2}$ - and $\mathrm{CH}_{4}$-enriched hydrothermal fluids of Socorro Island, Revillagigedo Archipelago, Mexico. Evidence for serpentinization and abiogenic methane. Geofluids 10 (4), 542-555.

Thode, H.G., Monster, J., Dunford, H.B., 1961. Sulfur isotope geochemistry. Geochim. Cosmochim. Acta 25, 159-174.

Tilley, B., Muehlenbachs, K., 2013. Isotope reversals and universal stages and trends of gas maturation in sealed, self-contained petroleum systems. Chem. Geol. 339, 194-204.

Vaselli, O., Tassi, F., Montegross, G., Capaccioni, B., Giannini, L., 2006. Sampling and analysis of volcanic gases. Acta Volcanol. 18 (1-2), 65-76.

Vinogradov, A.P., 1958. The isotopic composition of rocks of the Earth and of meteorites. Geochim. Cosmochim. Acta 15 (1-2), 80IN183-8290.

Werner, C., Christenson, B.W., Hagerty, M., Britten, K., 2006. Variability of volcanic gas emissions during a crater lake heating cycle at Ruapehu Volcano, New Zealand. J. Volcanol. Geotherm. Res. 154 (3), 291-302.

Zimmer, M.M. Fischer, T.P., Hilton, D.R, Alvarado, G.E. Sharp, Z.D, Walker, J.A, 2004 Nitrogen systematics and gas fluxes of subduction zones: insights from Costa Rica arc volatiles. Geochem. Geophys. 5 (5). 